Article

\title{
Increased Alveolar Heparan Sulphate and Reduced Pulmonary Surfactant Amount and Function in the Mucopolysaccharidosis IIIA Mouse
}

\author{
Tamara L. Paget ${ }^{1}$ (D), Emma J. Parkinson-Lawrence ${ }^{1}$, Paul J. Trim ${ }^{2}$, Chiara Autilio ${ }^{3}$, Madhuriben H. Panchal ${ }^{4}$, \\ Grielof Koster ${ }^{4}$, Mercedes Echaide ${ }^{3}$, Marten F. Snel ${ }^{2}$, Anthony D. Postle ${ }^{4}$, Janna L. Morrison ${ }^{5}$, Jésus Pérez-Gil ${ }^{3} \mathbb{D}$ \\ and Sandra Orgeig ${ }^{1, *}$
}

Citation: Paget, T.L.;

Parkinson-Lawrence, E.J.; Trim, P.J.; Autilio, C.; Panchal, M.H.; Koster, G.; Echaide, M.; Snel, M.F.; Postle, A.D.; Morrison, J.L.; et al. Increased Alveolar Heparan Sulphate and Reduced Pulmonary Surfactant Amount and Function in the Mucopolysaccharidosis IIIA Mouse. Cells 2021, 10, 849. https://doi.org/ 10.3390/cells10040849

Academic Editor: Ritva Tikkanen

Received: 11 February 2021

Accepted: 24 March 2021

Published: 8 April 2021

Publisher's Note: MDPI stays neutra with regard to jurisdictional claims in published maps and institutional affiliations.

Copyright: (c) 2021 by the authors. Licensee MDPI, Basel, Switzerland. This article is an open access article distributed under the terms and conditions of the Creative Commons Attribution (CC BY) license (https:// creativecommons.org/licenses/by/ $4.0 /)$.
1 Mechanisms in Cell Biology and Disease Group, UniSA Clinical and Health Sciences, University of South Australia, Adelaide, SA 5000, Australia; tamara.paget@mymail.unisa.edu.au (T.L.P.); emma.parkinson-lawrence@unisa.edu.au (E.J.P.-L.)

2 Proteomics, Metabolomics and MS-Imaging Core Facility, South Australian Health and Medical Research Institute, Adelaide, SA 5000, Australia; Paul.Trim@sahmri.com (P.J.T.); Marten.Snel@sahmri.com (M.F.S.)

3 Department of Biochemistry, Faculty of Biology and Research Institute Hospital 12 de Octubre (Imas12), Complutense University, 28003 Madrid, Spain; cautilio@ucm.es (C.A.); mechaide@pdi.ucm.es (M.E.); jperezgil@bio.ucm.es (J.P.-G.)

4 Faculty of Medicine, University of Southampton, Southampton SO16 6YD, UK; M.H.Panchal@soton.ac.uk (M.H.P.); G.Koster@soton.ac.uk (G.K.); A.D.Postle@soton.ac.uk (A.D.P.)

5 Early Origins Adult Health Research Group, Health and Biomedical Innovation, UniSA Clinical and Health Sciences, University of South Australia, Adelaide, SA 5000, Australia; janna.morrison@unisa.edu.au

* Correspondence: Sandra.Orgeig@unisa.edu.au; Tel.: +61-410-422-712

Abstract: Mucopolysaccharidosis IIIA (MPS IIIA) is a lysosomal storage disease with significant neurological and skeletal pathologies. Respiratory dysfunction is a secondary pathology contributing to mortality in MPS IIIA patients. Pulmonary surfactant is crucial to optimal lung function and has not been investigated in MPS IIIA. We measured heparan sulphate (HS), lipids and surfactant proteins (SP) in pulmonary tissue and bronchoalveolar lavage fluid (BALF), and surfactant activity in healthy and diseased mice (20 weeks of age). Heparan sulphate, ganglioside GM3 and bis(monoacylglycero)phosphate (BMP) were increased in MPS IIIA lung tissue. There was an increase in HS and a decrease in BMP and cholesteryl esters (CE) in MPS IIIA BALF. Phospholipid composition remained unchanged, but BALF total phospholipids were reduced (49.70\%) in MPS IIIA. There was a reduction in SP-A, $-\mathrm{C}$ and -D mRNA, SP-D protein in tissue and SP-A, $-\mathrm{C}$ and $-\mathrm{D}$ protein in BALF of MPS IIIA mice. Captive bubble surfactometry showed an increase in minimum and maximum surface tension and percent surface area compression, as well as a higher compressibility and hysteresis in MPS IIIA surfactant upon dynamic cycling. Collectively these biochemical and biophysical changes in alveolar surfactant are likely to be detrimental to lung function in MPS IIIA.

Keywords: MPS IIIA; Sanfilippo syndrome; pulmonary surfactant; respiratory dysfunction; heparan sulphate; bronchoalveolar lavage; surfactant proteins; lipids; captive bubble surfactometry; surface activity

\section{Introduction}

Mucopolysaccharidosis type IIIA (MPS IIIA, Sanfilippo syndrome) is one of a group of up to 70 devastating lysosomal storage diseases (LSD) [1-3], which occur as a result of dysfunctional lysosomes. MPS IIIA is caused by mutations in the lysosomal hydrolase gene, N-sulfoglucosamine sulfohydrolase (SGSH), which produces sulphamidase that normally catalyses the degradation of the glycosaminoglycan (GAG), heparan sulphate (HS), to monosaccharides and inorganic sulphate for recycling in the cell [4]. Sulphamidase deficiency causes partially degraded HS and components of the entire catabolic pathway 
to accumulate in the lysosomal organelles and substrates for hydrolysis by downstream lysosomal enzymes are no longer degraded [5]. Specifically, there is an accumulation of gangliosides GM2 and GM3 and cholesterol affecting neuropathology in the brain [4].

Whilst MPS IIIA has devastating consequences in the brain with severe neurological dysfunction and behavioural disturbances, other symptoms occur in the skeletal, immune, muscular, renal, endocrine and exocrine systems, in addition to disordered sleep patterns and respiratory issues [2,6-8]. MPS IIIA is frequently associated with severe respiratory infection in mid to late teenage years with pneumonia being the leading cause of death at the median age of 14.5 years in the severe phenotype $[6,9,10]$.

Primary lung involvement is not normally a symptom reported in the mucopolysaccharidoses at birth. Rather, respiratory symptoms manifest secondary to neurological and skeletal pathologies in the form of severe respiratory obstructions in upper and lower airways in MPS I, II, V and VI patients, and to a lesser extent in MPS IIIA patients [11]. However, respiratory distress was the primary presentation in two recent cases of MPS I [12] and one of MPS IIIA [5] where lung tissue biopsies showed interstitial cells with vacuolated cytoplasm containing a flocculent substrate, which was suggestive of GAG storage $[5,12]$. Significant pulmonary, and specifically alveolar involvement, have been confirmed in several LSD including Gaucher, Niemann-Pick types A and C2, Sandhoff and Sialidosis diseases [13-17], with not only the accumulation of lipids and other substrates, but a consequential alteration in the production of pulmonary surfactant (PS) leading to respiratory distress and dysfunction. Surfactant is produced and stored in alveolar epithelial type II cells, in special organelles, the lamellar bodies, belonging to the endosome-lysosome system which finally secrete surfactant into the liquid lining of the lung, where it forms a surface-active film at the air-liquid interface. Surfactant serves a dual role: to regulate the interfacial surface tension of the lung during the breathing cycle to reduce the work of breathing and in host defence as part of the innate immune system of the lung, where it protects against pulmonary-acquired pathogens. Therefore, compromise of the PS system may lead to symptoms including recurrent cases of ear, nose and throat infections, which present more frequently with age in the mucopolysaccharidoses [11].

Here, we hypothesised that the accumulation of undegraded heparan sulphate in the alveolar epithelium contributes to altered metabolism, including synthesis, secretion and composition of pulmonary surfactant in MPS IIIA, leading to impaired surface activity. The aim of this study was to describe alterations in pulmonary tissue storage of GAG, lipid and protein composition of lung tissue and pulmonary surfactant, and surfactant activity using a naturally occurring MPS IIIA mouse model. Impaired surfactant metabolism and activity may explain the increased susceptibility of MPS IIIA patients to respiratory infections and other pulmonary insults.

\section{Materials and Methods}

\subsection{Animals}

Wild type, heterozygous and homozygous MPS IIIA (CL57BL/6, D31N aspartate to asparagine mutation) mice were obtained from a breeding colony established and maintained at the Women's and Children's Health Network (WCHN) animal facility, Adelaide, South Australia [18]. The mouse model has approximately 3-4\% sulphamidase activity in the brain, kidney and liver, and closely mimic the pathological, biochemical and behavioural characteristics observed in humans $[18,19]$. Mice were kept in a standard 12:12 h light-dark cycle and had free access to pelleted food and water with standard care. All experiments were conducted with ethics approval obtained through the WCHN ethics committee (Ethics \#AE1054 and AEC1031/12/18).

\subsection{Tissue and Lavage (BALF) Collection}

Mice were humanely killed with sodium pentobarbitone (lethabarb 20-80 mg/100 g body weight) at approximately 20 weeks of age. Mice $(n=30$ wild type, 25 heterozygous and 55 MPS IIIA mice) were allocated to either tissue collection or bronchoalveolar lavage 
fluid (BALF) collection. Lung tissue was collected by dissecting the lungs and snapfreezing and storing at $-80{ }^{\circ} \mathrm{C}$ before analysis. BALF was collected from lungs in situ via tracheal 103 cannulation. Three separate volumes of ice-cold $0.9 \%(w / v)$ saline were each instilled into and withdrawn from the lungs 3 times to rinse the lungs of pulmonary surfactant. Recovered BALF was placed on ice before centrifuging $\left(150 \times \mathrm{g}, 5 \mathrm{~min}, 4^{\circ} \mathrm{C}\right)$. The supernatant was decanted and stored at $-80^{\circ} \mathrm{C}$ for later lipid extraction and analysis.

\subsection{Tissue Homogenisation}

Lung tissue samples were prepared for analysis by loading silica-bead tubes with $\sim 50 \mathrm{mg}$ tissue, $1 \mathrm{~mL}$ phosphate buffer and protease inhibitor $(2.5 \mu \mathrm{L} / 50 \mathrm{mg}$ tissue) (Roche Diagnostics, cOmplete protease inhibitor Mini cat\#04693159001) before homogenising (Precelly's 24, Bertin Technology) (6000 rpm, $10 \mathrm{~s}$, room temperature (RT)). Samples were centrifuged (Eppendorf centrifuge 5415R) $\left(500 \mathrm{~g}, 5 \mathrm{~min}, 4^{\circ} \mathrm{C}\right)$ to pellet the debris. The supernatant was collected and stored at $-80{ }^{\circ} \mathrm{C}$. Total protein quantification in lung homogenates was determined using a micro bicinchoninic acid (BCA) protein assay kit (Thermo Scientific Inc., Melbourne, VIC, Australia Cat\# PN 23 227). Bovine serum albumin was used to generate the standard curve.

\subsection{Sample Preparation and Analysis_-Heparan Sulphate}

Heparan sulphate in tissue and BALF samples was depolymerised and desulphated to prepare alkylated disaccharides by butanolysis according to published methods [20]. Briefly, BALF $(900 \mu \mathrm{L})$ samples were freeze dried overnight. 2,2-dimethoxypropane (50 $\mu \mathrm{L})$ and butanolic $\mathrm{HCl}(3 \mathrm{M}, 1000 \mu \mathrm{L})$ were added to BALF and tissue lysate samples, sealed and incubated $\left(100{ }^{\circ} \mathrm{C}, 2 \mathrm{~h}\right)$. Samples were dried under nitrogen $\left(45^{\circ} \mathrm{C}, 1 \mathrm{~h}\right)$ before being reconstituted with $200 \mu \mathrm{L}$ d9 disaccharide internal standard (IS). Solutions were mixed (30 min) on an orbital shaker (Ratek Instruments, Boronia, VIC, Australia) and centrifuged (Biofuge pico centrifuge, Heraeus, Germany) (13,000 rpm, $15 \mathrm{~min})$. Standards were prepared using disaccharide standard at 1, 5, 20,100, 500, 1000 and $1500 \mathrm{ng}$. Blanks consisted of MilliQ water and $0.1 \%$ Trifluoroacetic acid (TFA). Sample supernatant $(80 \mu \mathrm{L})$ and disaccharide standards were loaded into a 96-well microtiter plate, sealed with foil and placed at $6{ }^{\circ} \mathrm{C}$ in the sample manager for analysis.

Liquid chromatography-tandem mass spectrometry (LC-MS/MS) analysis was performed using an Acquity UPLC (Waters Corporation, Milford, MA, USA) equipped with a $2.1 \mathrm{~mm}$ ID $\times 50 \mathrm{~mm}$ BEH C18 (1.7 $\mu \mathrm{m}$ particle) analytical column (P/N. 186002350) and an API 4000 QTrap mass spectrometer (ABSciex, Concord, ON, Canada). A random order run was created on the mass spectrometry software prior to commencing the run. Initial blank and quality control samples were in specific positions in the run. Samples were analysed interspersed every three injections with a blank injection of MilliQ water $/ 0.1 \%$ TFA. A binary solvent system was used; solvent A consisting of water with $0.1 \%$ formic acid (FA) and solvent B consisting of acetonitrile with $0.1 \%$ FA. Sample injection $(2 \mu \mathrm{L})$ was loaded on the column at a flow rate of $350 \mu \mathrm{L} / \mathrm{min}$ using $99 \%$ solvent A. The LC system was conditioned ( $2 \mathrm{~min}$ ) prior to the commencement of the analysis. Chromatographic separation was performed using the gradient shown in Table 1.

Table 1. Chromatographic gradient used for the analysis of butanolic products of HS.

\begin{tabular}{cccc}
\hline Time & $\begin{array}{c}\text { Solvent A } \\
(\mathbf{\%})\end{array}$ & $\begin{array}{c}\text { Solvent B } \\
(\mathbf{\%})\end{array}$ & $\begin{array}{c}\text { Flow } \\
(\boldsymbol{\mu L} / \mathbf{m i n})\end{array}$ \\
\hline $\mathbf{0 . 0 1}$ & 99 & 1 & 0.350 \\
$\mathbf{2 . 0 0}$ & 95 & 5 & 0.350 \\
$\mathbf{2 . 0 1}$ & 80 & 20 & 0.350 \\
$\mathbf{5 . 0 0}$ & 75 & 25 & 0.350 \\
$\mathbf{5 . 0 1}$ & 1 & 99 & 0.350 \\
$\mathbf{7 . 5 0}$ & 99 & 1 & 0.350 \\
$\mathbf{8 . 5 0}$ & 99 & 1 & 0.350 \\
\hline
\end{tabular}


Data were acquired in multiple reaction monitoring (MRM) mode. In this mode six transitions were monitored for $50 \mathrm{~ms}$ each, $m / z 468.245$ to 162.077 (butanolysis product), and $m / z 477.300$ to 162.077 (d9 Disaccharide IS). The peak areas were calculated using Analyst 1.6.2 (AB/Sciex). Although there were multiple peaks present following butanolysis of HS, the dominant peak was integrated for the analysis. The peaks relating to the chondroitin sulphate/dermatan sulphate transition were generally not detected in samples prepared by butanolysis.

\subsection{Sample Preparation and Analysis_Gangliosides, Bis(Monoacylglycero)Phosphate (BMP), and Cholesterol}

The Folch extraction method was used to prepare samples for analysis [21]. Briefly, BALF samples $(90 \mu \mathrm{L})$ were freeze dried and reconstituted with MilliQ water $(100 \mu \mathrm{L})$. Internal standards were added to BALF and tissue samples (100 $\mu \mathrm{g}$ protein) to enable quantification. $\mathrm{CHCl}_{3} / \mathrm{CH}_{3} \mathrm{OH}(2 \mathrm{~mL})$ was added prior to mixing on a tube rotator (40 rpm, $10 \mathrm{~min}$ ) and standing (RT, $50 \mathrm{~min})$. MilliQ water $(400 \mu \mathrm{L})$ was added, mixed on a tube rotator $(40 \mathrm{rpm}, 10 \mathrm{~min}$ ) and then centrifuged (3500 rpm, $5 \mathrm{~min}$ ). Resultant layers were transferred as follows: upper aqueous layers to glass tubes for ganglioside extraction procedure and lower hydrophobic phase to two glass tubes for BMP and cholesterol analysis, respectively ( $\sim 50 \mu \mathrm{L}$ each).

For ganglioside extraction, $\mathrm{C} 18(200 \mathrm{mg})$ columns were primed with $3 \times 1 \mathrm{~mL} \mathrm{CH} 3 \mathrm{OH}$ followed by $3 \times 1 \mathrm{~mL}$ MilliQ water and loaded with sample. Columns were washed with $1 \times 1 \mathrm{~mL}$ MilliQ water before eluting gangliosides with $3 \times 1 \mathrm{~mL} \mathrm{CH}_{3} \mathrm{OH}$ into $10 \mathrm{~mL}$ glass tubes, followed by brief vacuum drying. Samples were dried under nitrogen $\left(38^{\circ} \mathrm{C}\right)$ before resuspending in $100 \mu \mathrm{L} 10 \mathrm{mM} \mathrm{NH}_{4} \mathrm{COOH}$ in $\mathrm{CH}_{3} \mathrm{OH}$ and centrifuging (3500 rpm, $5 \mathrm{~min}$ ). Supernatant $(80 \mu \mathrm{L})$ was transferred into a 96-well microtitre plate for analysis.

For BMP extraction, samples were dried under nitrogen at $38{ }^{\circ} \mathrm{C}$, resuspended in $200 \mu \mathrm{L} 10 \mathrm{mM} \mathrm{NH}_{4} \mathrm{COOH}$ in $\mathrm{CH}_{3} \mathrm{OH}$ and vortexed briefly before centrifuging (3500 rpm, $5 \mathrm{~min})$. The supernatant ( $\sim 25 \mu \mathrm{L} /$ sample) was transferred to a 96-well microtiter plate for analysis.

For the cholesterol esterification reaction, samples were dried under nitrogen at $38^{\circ} \mathrm{C}$. Anhydrous acetyl chloride $/ \mathrm{CHCl}_{3}(1: 5 \mathrm{v:v})(100 \mu \mathrm{L})$ was added, the vial sealed, vortexed ( $1 \mathrm{~min}$ ) and allowed to stand (RT, $1 \mathrm{~h}$ ). Samples were dried under nitrogen at $38{ }^{\circ} \mathrm{C}$, reconstituted in $200 \mu \mathrm{L} \mathrm{100 \%} \mathrm{CH}_{3} \mathrm{OH} / 10 \mathrm{mM} \mathrm{NH}_{4} \mathrm{COOH}$ and centrifuged (3500 rpm, $5 \mathrm{~min})$. Supernatant $(\sim 80 \mu \mathrm{L})$ was transferred into a 96 well microtitre plate for analysis.

Liquid chromatography-tandem mass spectrometry (LC-MS/MS) analysis was performed using a Shimadzu LC-20AD binary pump system combined with an ABSciex API 4000 QTrap mass spectrometer equipped with Analyst software (Version 1.4.2) and a turboionspray source. Liquid chromatography separation was achieved by injecting samples $(20 \mu \mathrm{L})$ onto a $3 \mu \mathrm{m}$ Alltima C18 column $(50 \times 2.1 \mathrm{~mm})$ at $200 \mu \mathrm{L}$. The HPLC gradient program began with $70 \%$ mobile phase A (30\% tetrahydrofuran/20\% $\mathrm{CH}_{3} \mathrm{OH} / 50 \% 5 \mathrm{mM}$ $\mathrm{NH}_{4} \mathrm{COOH}$ in $\mathrm{H}_{2} \mathrm{O}$ ) followed by a linear ramp (0.01-7.0 min) to $100 \%$ mobile phase $\mathrm{B}(70 \%$ tetrahydrofuran $/ 20 \% \mathrm{CH}_{3} \mathrm{OH} / 10 \% 5 \mathrm{mM} \mathrm{NH}_{4} \mathrm{COOH}$ in $\mathrm{H}_{2} \mathrm{O}$ ) and maintained for $3 \mathrm{~min}$. Re-equilibration at $70 \%$ mobile phase A was performed for $3 \mathrm{~min}$ prior to the next injection. A Valco 10-port post column valve diverted column flow to waste for the first $1.7 \mathrm{~min}$.

Mass spectrometric analysis of gangliosides was performed in negative ion multiple reaction monitoring mode using an ionspray temperature of $200^{\circ} \mathrm{C}$ and voltage of $-5000 \mathrm{~V}$. Nitrogen was used as the collision gas at a pressure of $2 \times 10^{-5}$ Torr. Concentrations of each molecular species were calculated by relating the peak areas of each species to the peak area of the corresponding internal standard using Analyst 1.6.2 software.

Mass spectrometric analysis of cholesterol and BMP was performed in positive ion multiple reaction monitoring mode using an ionspray temperature of $200{ }^{\circ} \mathrm{C}$ and voltage of $5000 \mathrm{~V}$. Nitrogen was used as the collision gas at a pressure of $2 \times 10^{-5}$ Torr. Relative cholesterol levels were determined by relating the peak area of $C_{2}$ cholesterol to the peak area of C17 cholesterol internal standard. BMP molecular species were differentiated from phosphatidylglycerol by their molecular ion fragmentation in positive mode. This 
allowed identification of both acyl carbon chains for BMP. Concentrations of each molecular species were calculated by relating the peak areas of each species to the peak area of the corresponding internal standard using Analyst 1.6.2 software.

\subsection{Tissue and Lavage Collection for Total Phospholipid Pool Analysis}

Control and MPS IIIA mice (as detailed in Section 2.1) used in the phospholipid pool analysis were collected as part of a larger cohort designed to measure a phosphatidylcholine kinetics time course following intraperitoneal injection of D9 choline chloride (Ethics \#AE1054). Here, we presented only the data from the $0 \mathrm{~h}$ time point, in which mice were not injected with the isotope. Following very deep anaesthesia that was administered via intraperitoneal injection of xylazine $(10 \mathrm{mg} / \mathrm{kg}) / \mathrm{ketamine}(100 \mathrm{mg} / \mathrm{kg})$, the chest cavity was opened, blood collected from the heart, and a sample of liver collected. Plasma was separated and both plasma and liver samples were snap frozen for future phospholipid analysis. Both lungs were lavaged via tracheal cannulation and the BALF prepared and frozen as per Section 4.2. Lavage recovery was $84.5 \pm 8.8 \%$ from $n=9$ control, 14 MPS IIIA samples, which is similar to that reported previously [22]. The left lung lobe was snap frozen to use for lung tissue phospholipid analysis ( $n=16$ control, 14 MPS IIIA samples) and the right lung lobes were excised and chilled in $0.25 \mathrm{M}$ sucrose to isolate lamellar bodies (no data shown). Samples were transported on dry ice to Southampton, UK, for mass spectrometry analysis.

\subsection{Sample Preparation and Analysis-Total Phospholipids}

Lavaged lung tissue, with $10 \mu \mathrm{L}$ of the antioxidant butylated hydroxyl toludene (BHT) added, was homogenised in saline using a Heidolph Silent Crusher S prior to storing $\mathrm{a}-80^{\circ} \mathrm{C}$. Phospholipids were extracted from both lung tissue homogenates and BALF using the method of Bligh and Dyer [23]. BALF samples were thawed and $800 \mu \mathrm{L}$ of each sample was removed before the addition of $10 \mu \mathrm{L}$ of BHT. To the $800 \mu \mathrm{L}$ aliquots each, of tissue homogenate and BALF, $100 \mu \mathrm{L}$ of an internal standard mixture of synthetic lipids (Table 2) was added. Samples were vortexed prior to lipid extraction using a Freedom EVO 100 robotic liquid handling system (Tecan, Theale, UK). The robot was programmed to add $2 \mathrm{~mL}$ methanol, $2 \mathrm{~mL}$ dichloromethane (DCM) and $1 \mathrm{~mL}$ of distilled water to each sample and mixed well to allow for the formation of a biphasic mixture; the lower DCM layer containing phospholipids and an aqueous upper layer. Samples were centrifuged ( $3000 \mathrm{rpm}, 10 \mathrm{~min}, 20^{\circ} \mathrm{C}$ ) and the lipid layer removed by the robot before being dried under a stream of warmed nitrogen gas (Ultravap, Porvair, Norfolk, UK) for $40 \mathrm{~min}$. Samples were stored at $-80^{\circ} \mathrm{C}$ until they were analysed by mass spectrometry.

Table 2. Internal standard composition $100 \mu \mathrm{L}$ per sample.

\begin{tabular}{lc}
\hline \multicolumn{1}{c}{ Standard Name } & $\begin{array}{c}\text { nmol Added to Each } \\
\text { Sample at Extraction }\end{array}$ \\
\hline Dimyristoyl-phosphatidylcholine (DMPC) & 10 \\
Dimyristoyl phosphatidylethanolamine (DMPE) & 4 \\
Dimyristoyl phosphatidylserine (DMPS) & 2 \\
Dimyristoyl phosphatidylglycerol (DMPG) & 2 \\
Dimyristoyl phosphatidic acid (DMPA) & 1 \\
Lysophosphatidylcholine (LPC17:0) & 1 \\
Sphingomyelin (SM16:0) & 1 \\
Ceramide 12:0 & 2 \\
Triacylglycerol (TAG) & 10 \\
\hline
\end{tabular}

Mass spectrometry was performed on phospholipids using electrospray ionisation (ESI) (Waters XEVO TQ-MS). Dried BALF samples were dissolved in $1 \mathrm{~mL} 66 \% \mathrm{CH}_{3} \mathrm{OH}$, $30 \%$ DCM and $4 \% \mathrm{C}_{2} \mathrm{H}_{7} \mathrm{NO}_{2}\left(300 \mathrm{mM}\right.$ in $\left.\mathrm{H}_{2} \mathrm{O}\right)$. Two hundred $\mu \mathrm{L}$ was used from each sample to prepare a pooled Analytical Quality Control (AQC) sample for each genotype. The sample solution was infused using the loop injection method into the mass spectrometer 
(HP1100 Agilent HPLC) at $0.005 \mathrm{~mL} / \mathrm{min}$ using $99 \% \mathrm{CH}_{3} \mathrm{OH}$ with $1 \%$ acetic acid with a series of multiple injections. Diagnostic MS/MS scans were carried out in positive and negative mode (Table 3) and analysis was conducted as indicated in diagnostic MS/MS scans for head groups (Supplementary Materials-Table S1). Measuring time for each sample varied between 35 and 90 min with 5 min cleaning injection (60\% methanol, 30\% dichloromethane and $10 \%$ acetic acid) after every sample. The pooled AQC was run with between 5 to 6 samples for each mouse genotype and with each genotype at the start and at the end of each batch. This extended analysis time enabled a comprehensive range of diagnostic MS/MS scans to be performed, detailed below and summarised in Supplementary Materials-Table S1.

a. Positive and negative ESI scans were performed for each sample using an injection volume of $50 \mu \mathrm{L}$ and an analysis time of $13 \mathrm{~min}$, measuring the total number of ionised molecules in the samples. This was a control for the presence of any contaminants and overall signal intensity and were not used for ion peak assignments.

b. Diagnostic MS/MS precursor scans were performed with the second injection $(100 \mu \mathrm{L})$ and analysis time of 22.40 min to quantify PC. Scans were based on the detection of the major collision-induced dissociation (CID) phosphorylcholine fragment ion, detected at $m / z 184$.

c. The third injection $(100 \mu \mathrm{L}$, analysis $22.40 \mathrm{~min})$ included neutral loss (NL) scans for the DPPC molecule and diagnostic scans for the other major phospholipid classes, P153 for acidic phospholipids, P241 for phosphatidylinositol (PI), NL141 for phosphatidylethanolamine (PE) and NL87 for phosphatidylserine (PS).

d. The final injection $(100 \mu \mathrm{L}$, analysis $22.40 \mathrm{~min})$ included precursor scans to determine the distributions of fatty acyl moieties. Each of the lipids indicated Supplementary Materials-Table S1) were detected by the indicated type of scan to provide a comprehensive analysis of unlabelled phospholipids.

Table 3. ESI Diagnostic MS/MS scans.

\begin{tabular}{cccc}
\hline MS & Scan & MS/MS Mode & Range $(\boldsymbol{m} / \mathbf{z})$ \\
\hline ES+ & a & Full positive & $2-1300$ \\
ES- & a & Full Negative & $2-1300$ \\
ES- & a & Partial Negative & $400-900$ \\
\hline
\end{tabular}

$\mathrm{a}=$ first injection.

For molecular species analysis mass spectrometry provided a generic formula based on the total number of carbon atoms and unsaturated double bonds in each lipid class (Supplementary Materials-Table S1). Based on previous analyses [24,25] and MS/MS fragmentation in negative ionisation to generate diagnostic fatty acyl residues, column 2 (Supplementary Materials-Table S2) identifies the most probable molecular structures. Here, designations are given as PXa:y/b: $x$ for each phospholipid class, where $\mathrm{X}$ represents the headgroup base (e.g., choline or glycerol), a and b are the number of carbon atoms in the sn- 1 and sn-2 fatty acyl residues and $y$ and $x$ are numbers of double bonds.

\subsection{Captive Bubble Surfactometry (CBS)}

BALF precipitant ( $n=10$ control, 6 MPS IIIA) was prepared by ultracentrifugation (Beckman Optima L-90K; SW65Ti rotor; 31,000 rpm; $4{ }^{\circ} \mathrm{C} ; 1 \mathrm{~h}$ ) and resuspended in $\sim 10 \mu \mathrm{L}$ supernatant and placed in a bath sonicator for $8 \mathrm{~min}$. PC was assayed in duplicate using previously published enzymatic methods (Spinreact, St. Esteve de Bas, Girona, Spain) [26-28] and samples reconstituted with phosphate buffered saline to a PC concentration of $20 \mathrm{mg} / \mathrm{mL}$. For CBS analysis $200 \mathrm{~nL}$ of the surfactant suspension was applied to the surface of a $0.05 \mathrm{~mL}$ air bubble created inside a buffer-filled ( $5 \mathrm{mM}$ Tris, $150 \mathrm{mM} \mathrm{NaCl}, \mathrm{pH} 7$ and $5 \%$ sucrose $)$ thermostatically controlled $\left(37^{\circ} \mathrm{C}\right)$ chamber. The bubble was compressed and expanded periodically using hydrostatic pressure delivered by a piston. CBS mimics the respiratory cycle changes in alveolar volumes so that surface-active properties under 
dynamic compression-expansion conditions are measured at the air-liquid interface of the air bubble. Variations in the bubble shape were continuously recorded and analysed using the custom-designed CBS software, facilitating the calculation of volume, area and surface tension at all times [29]. For each sample, CBS measurements were carried out in triplicate at $37^{\circ} \mathrm{C}$ according to the following protocol. After initial adsorption for $5 \mathrm{~min}$, the chamber was sealed and the bubble expanded to $0.15 \mathrm{~mL}$. Post-expansion adsorption was measured for another $5 \mathrm{~min}$. Thereafter a single quasi-static compression cycle was completed to determine the bubble size limits for step-wise $20 \%$ compressions to a final minimum bubble size of $\sim 15 \%$ of maximum. Thereafter, the bubble was cycled continuously for 30 cycles at 30 cycles $/ \mathrm{min}$. The changes in bubble shape were monitored continuously and related to changes in surface tension $(\gamma)$.

\subsection{Gene Expression Using Quantitative Real-Time PCR}

Total RNA was extracted from $\sim 50 \mathrm{mg}$ lung tissue using Qiagen QIAzol Lysis Reagent and Qiagen RNeasy purification columns (Qiagen Pty Ltd., Doncaster, VIC, Australia) according to the manufacturer's instructions and as previously described [30-32]. Total RNA was quantified using spectrophotometric measurements at 260 and $280 \mathrm{~nm}$ while the integrity of purified RNA was verified by assessment of the RNA bands run on an agarose gel stained with ethidium bromide.

cDNA was synthesised according to the manufacturer's guidelines with a Superscript III First Strand Synthesis System (Invitrogen, Carlsbad, CA, USA), using $2 \mu \mathrm{g}$ total diluted RNA, random hexamers, dNTP, DTT and Superscript III in a final volume of $20 \mu \mathrm{L}$. A no template control (NTC) containing no RNA transcript and a no amplification control (NAC) containing no Superscript III were used to check for contamination of reagents or genomic DNA, respectively [33].

Primer sets for target genes (surfactant proteins) and housekeeping genes were designed from the NCBI database (Table 4). All primer pairs were optimised and validated to determine the minimum primer concentration to yield the maximum response.

Table 4. qRT-PCR primer sequences and optimal primer concentrations for housekeeping genes and genes of interest.

\begin{tabular}{|c|c|c|}
\hline Gene & Primer Sequence $\left(5^{\prime} \rightarrow 3^{\prime}\right)$ & $\begin{array}{l}\text { Accession } \\
\text { Numbers }\end{array}$ \\
\hline АСТВ & $\begin{array}{l}\text { FWD-AGCTGTGCTATGTTGCTC } \\
\text { REV-CACTTCATGATGGAATTGAATGTAG }\end{array}$ & BC138614.1 \\
\hline HPRT1 & $\begin{array}{l}\text { FWD-GCTGGATTACATTAAAGCACTGAAT } \\
\text { REV-AAAGTTTGCATTGTTTTACCAGTGT }\end{array}$ & NM_013556 \\
\hline YWHAZ & $\begin{array}{l}\text { FWD-TTGAGCAGAAGACGGAAGGT } \\
\text { REV-GAAGCATTGGGGATCAAGAA }\end{array}$ & NM_011740 \\
\hline PGK1 & $\begin{array}{l}\text { FWD-GTCGTGATGAGGGTGGACTT } \\
\text { REV-TTTGATGCTTGGAACAGCAG }\end{array}$ & NM_008828 \\
\hline RpPo1 & $\begin{array}{l}\text { FWD-CAACCCTGAAGTGCTTGACAT } \\
\text { REV-AGGCAGATGGATCAGCCA }\end{array}$ & NM_007475.5 \\
\hline PPIA & $\begin{array}{l}\text { FWD-ACCAAACACAAACGGTTCCC } \\
\text { REV-TGCCTTCTTTCACCTTCCCAAA }\end{array}$ & NM_008907.1 \\
\hline SP-A & $\begin{array}{l}\text { FWD-TTTCCACCAATGGGCAGTCA } \\
\text { REV-AGAAGCCCCATCCAGGTAGT }\end{array}$ & NM_023134 \\
\hline SP-B & $\begin{array}{l}\text { FWD-GCTACTGCTGCTTCCTACCC } \\
\text { REV-TGGCACAGGTCATTAGCTCC }\end{array}$ & NM_147779 \\
\hline SP-C & $\begin{array}{l}\text { FWD-GGAGCACCGGAAACTCAGAA } \\
\text { REV-GGAGCCGCTGGTAGTCATAC }\end{array}$ & NM_011359 \\
\hline SP-D & $\begin{array}{l}\text { FWD-AGCCCAACAACAATGGTGGA } \\
\text { REV-CACAGATAACAAGGCGCTGC }\end{array}$ & NM_009160 \\
\hline
\end{tabular}


The geNorm component of the qBase 2.0 relative quantification model (Biogazelle) was used to select the most stable of the genes. Based on this model, ribosomal protein P0 (RpP0), tyrosine 3-monooxygenase/tryptophan 5-Monooxygenase Activation Protein Zeta (YWAHZ) and peptidylprolyl isomerase A (PPIA) were stably expressed across the control and MPS IIIA groups and hence were selected from the candidate reference genes (Table 4) to act as internal standards in the following real time PCR analyses, which followed the MIQE guidelines [32].

Gene expression was determined by qRT-PCR using Fast SYBR Green master mix (Applied Biosystems) in a final volume of $6 \mu \mathrm{L}$ using a ViiA7 Fast Real-Time PCR machine (Applied Biosystems). Using DataAssist 3.0 (Life Technologies), all surfactant proteins (SP-A, -B, -C and -D) were normalised to the geometric mean of the three most stable housekeeping genes; RpPO, PPIA and YWHAZ. Each well on the qRT-PCR plate contained $1 \mu \mathrm{L}$ of $\mathrm{cDNA}, 3 \mu \mathrm{L}$ FastSYBRGreen Master Mix $(2 \times)$, and $2 \mu \mathrm{L}$ of forward and reverse primer (Table 4) mixed with differing amounts of $\mathrm{H}_{2} \mathrm{O}$ depending on the required final primer concentrations. NTCs for each primer set were included on each plate to check for non-specific amplification. The threshold was set within the exponential growth phase of the amplification curve and the corresponding cycle threshold $(\mathrm{Ct})$ values were obtained to quantify each reaction. A standard curve was obtained by plotting $\mathrm{Ct}$ values against the log of cDNA template concentrations. Gene expression was determined by qBase 2.0 relative quantification analysis software (Biogazelle) and expressed as mean normalised expression (MNE).

\subsection{Protein Expression Using Western Blot Analysis}

Tissue lysate homogenisation for Western blot analysis was completed as per Section 2.2. Quantitative Western blot analysis for lung tissue and BALF samples were optimised using the methods, principles and guidelines described by Pillai-Kastoori et al. [34]. Optimal loading efficiency for each of the primary antibodies was determined using antibody validation and linear range analysis (Empiria Studio Software, Millennium Science, Mulgrave, VIC, Australia).

Samples for SP-A and -D analyses were reduced prior to sodium dodecyl sulfate polyacrylamide gel electrophoresis (SDS-PAGE) using 4-12\% bis-tris gels (Thermo Scientific cat\# NW04125BOX). Samples for SP-B were analysed under non-reducing conditions, and SP-C analysis under reducing conditions before SDS-PAGE using 16\% tricine gels (Thermo Scientific cat\# EC66955BOX). Protein transfer to PVDF membrane was performed using the Iblot2 transfer system (Thermo Scientific, Melbourne, VIC, Australia). Total protein analysis used Revert total protein stain (Millennium Science Cat\#LCR-926-11021) and fluorescence imaging $(700 \mathrm{~nm})$ Odyssey ${ }^{\circledR}$ CLX, Millennium Science, Melbourne, VIC, Australia) (Kirshner \& Gibbs, 2018) prior to blocking in Odyssey ${ }^{\circledR}$ TBS blocking buffer. Membranes were incubated overnight $\left(4^{\circ} \mathrm{C}\right.$, rocking) in primary antibody (SP-A Antihuman SP-A Rabbit polyclonal Thermo Scientific Cat\#PA5-76699; SP-B Anti-Mature SPB Rabbit polyclonal SevenHills Bioreagents Cat\#WRAB48604; SP-C Anti-Mature SP-C Rabbit polyclonal SevenHills Bioreagents Cat\#WRAB-MSPC; SP-D tissue Anti-mouse SP-D Rabbit polyclonal Chemicon International Cat\#AB3434 and SP-D BALF Anti-SP-D Rabbit polyclonal Thermo Scientific Cat\#PA5-81476). Membranes were then incubated in secondary antibody for $1 \mathrm{~h}$ (IRDye 800CW Donkey anti-rabbit IgG Millennium Science Cat\#LCR-925-32213 or IRDye 800CW Goat anti-rabbit IgG Millenium Science Cat\#LCR925-32211). Image analysis was performed using the Odyssey ${ }^{\circledR}$ CLX and Image Studio ${ }^{\mathrm{TM}}$ Lite Quantification Software (Millennium Science, Melbourne, VIC, Australia). All samples were measured in triplicate. Post image analysis was performed using Image Studio ${ }^{\mathrm{TM}}$ Lite Quantification software. Surfactant protein was normalised to total protein and data were expressed as arbitrary units. 


\subsection{Statistics}

Graphical representation and statistical analyses of data were performed using the software package GraphPad Prism 8.3.1 (GraphPad Software, San Diego, CA, USA. www.graphpad.com, accessed on 8 April 2021). As there was negligible HS present in the heterozygous control lung tissue, indicating that there is very little primary storage, the wildtype and heterozygous samples were combined to create a control group and compared with the MPS IIIA samples. Individual results for WT and heterozygous samples are provided in Supplementary Material-Table S3. Control and MPS IIIA groups were analysed using the two-tailed Students t-test, unless stated otherwise, and presented as mean $\pm \mathrm{SD} ; p<0.05$ was considered significant.

\section{Results}

3.1. Heparan Sulphate and Lipid Analyses by Liquid Chromatography Tandem Mass Spectrometry 3.1.1. Presence of Heparan Sulphate (HS) in Lung Tissue and Bronchoalveolar Lavage Fluid (BALF)

The amount of HS in lung tissue ( $3511 \pm 584.5 \mathrm{ng} / \mathrm{mg}$ protein, $n=11)$ and BALF $(400.2 \pm 98.3 \mathrm{ng} / \mathrm{mL}$ BALF, $n=13)$ of MPS IIIA mice was significantly greater when compared to that of wild type (lung tissue: $64.85 \pm 9.0 \mathrm{ng} / \mathrm{mg}$ protein, $n=9$; BALF: $14.78 \pm 4.0 \mathrm{ng} / \mathrm{mL}$ BALF) and heterozygous mice $(75.13 \pm 25.5 \mathrm{ng} / \mathrm{mg}$ protein, $n=9$; BALF: $18.86 \pm 8.2 \mathrm{ng} / \mathrm{mL}$ BALF, $n=7$ ). As there was negligible difference in HS measures between wild type and heterozygous mice, we combined the HS measures for wild type and heterozygous mice to make a single control group for HS (Figure 1A,B). The data for wild type and heterozygous animals were combined into a single control group for all further analyses. The data (mean $\pm \mathrm{SD}$ ) for the individual and combined groups for all analytes are presented in Supplementary Materials_-Table S3.

Heparan Sulphate - tissue

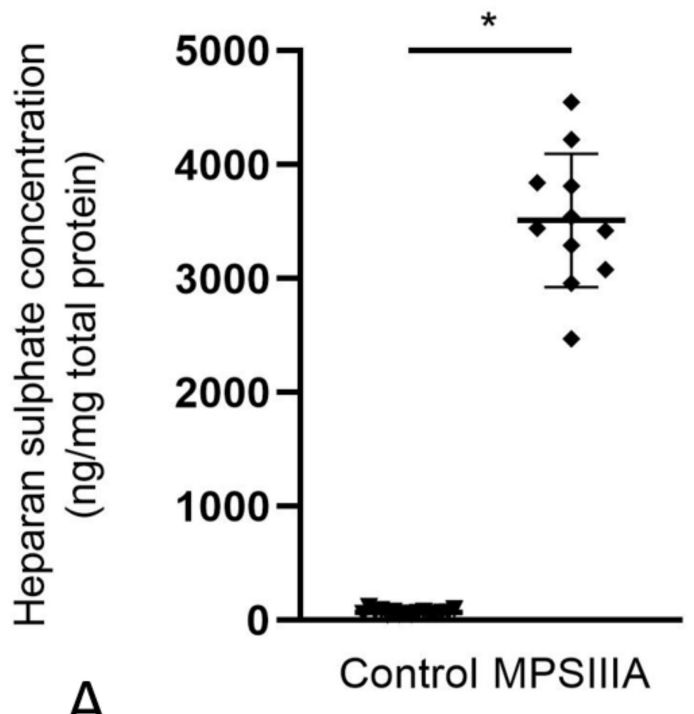

Heparan Sulphate - BALF

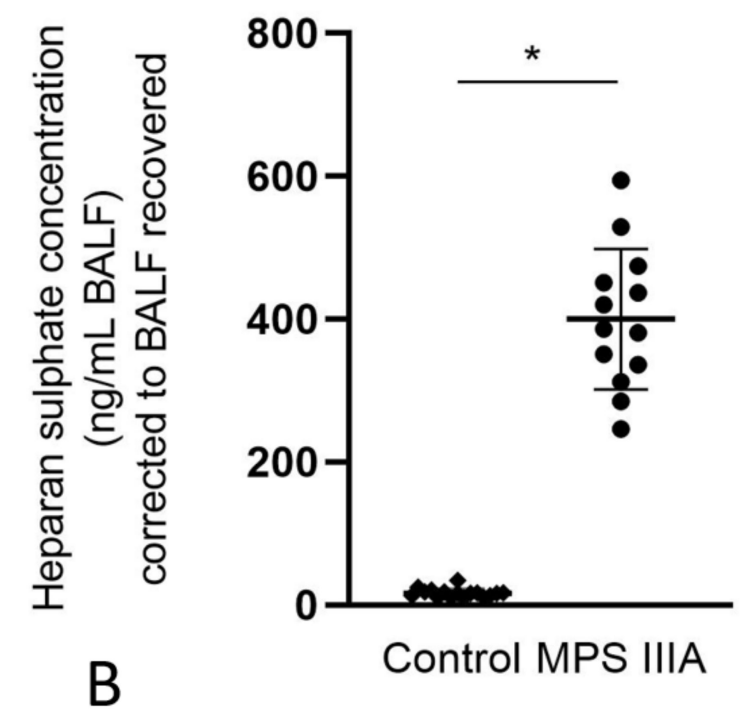

Figure 1. Heparan sulphate analysis in control (i.e., wild type and heterozygous combined) and MPS IIIA mice. HS accumulation in lung homogenates (A) and BALF (B) of 20-week control and MPS IIIA mice. HS was measured by LC-MS/MS using an API 4000 QTrap mass spectrometer (ABSciex) coupled with Acquity UPLC (Waters Corp). Data for A and $\mathrm{B}$ are expressed as disaccharide concentration ( $\mathrm{ng} / \mathrm{mg}$ total protein and $\mathrm{ng} / \mathrm{mL}$ BALF, respectively) and plotted as mean \pm SD; * indicates a significant difference between control and MPS IIIA mice. Two-tailed Students $t$-tests, $p<0.0001$, $n=17$ control and 11 MPS IIIA samples for lung tissue, $n=16$ control and 13 MPS IIIA samples for BALF. 


\subsubsection{Alterations in Ganglioside Concentration in Lung Tissue}

Gangliosides are sialic acid-containing glycosphingolipids. GM3 gangliosides contain three monosaccharide groups attached to a ceramide backbone that consists of a sphingoid base and a fatty acid linked by an amide bond. Different species of GM3 are determined by the fatty acid moieties, which are denoted as $\mathrm{d} 18: 1 / \mathrm{A}: \mathrm{x}$, where $\mathrm{A}$ is the number of carbon atoms and $x$ is the number of double bonds in the fatty acid. The concentration of two of the GM3 ganglioside molecular species d18:1/16:0 and d18:1/22:0 were significantly increased in the lung tissue of MPS IIIA mice when compared to controls (Figure 2). There was no significant difference in the remaining GM3 molecular species nor in GM1 ganglioside concentration in lung tissue between control and MPS IIIA mice (Supplementary MaterialsTable S3) and GM2 gangliosides were below the level of quantitation.

3.1.3. Alterations in Bis(Monoacylglycerol)Phosphate (BMP) Concentration in Lung Tissue and BALF

Total BMP measured in lung homogenates of 20-week old MPS IIIA mice showed a significant increase when compared to control mice (Figure 3). Further extrapolation of the data showed a significant increase in nine of sixteen molecular species (Figure 4, Supplementary Materials-Table S3).

\section{Ganglioside - GM3}

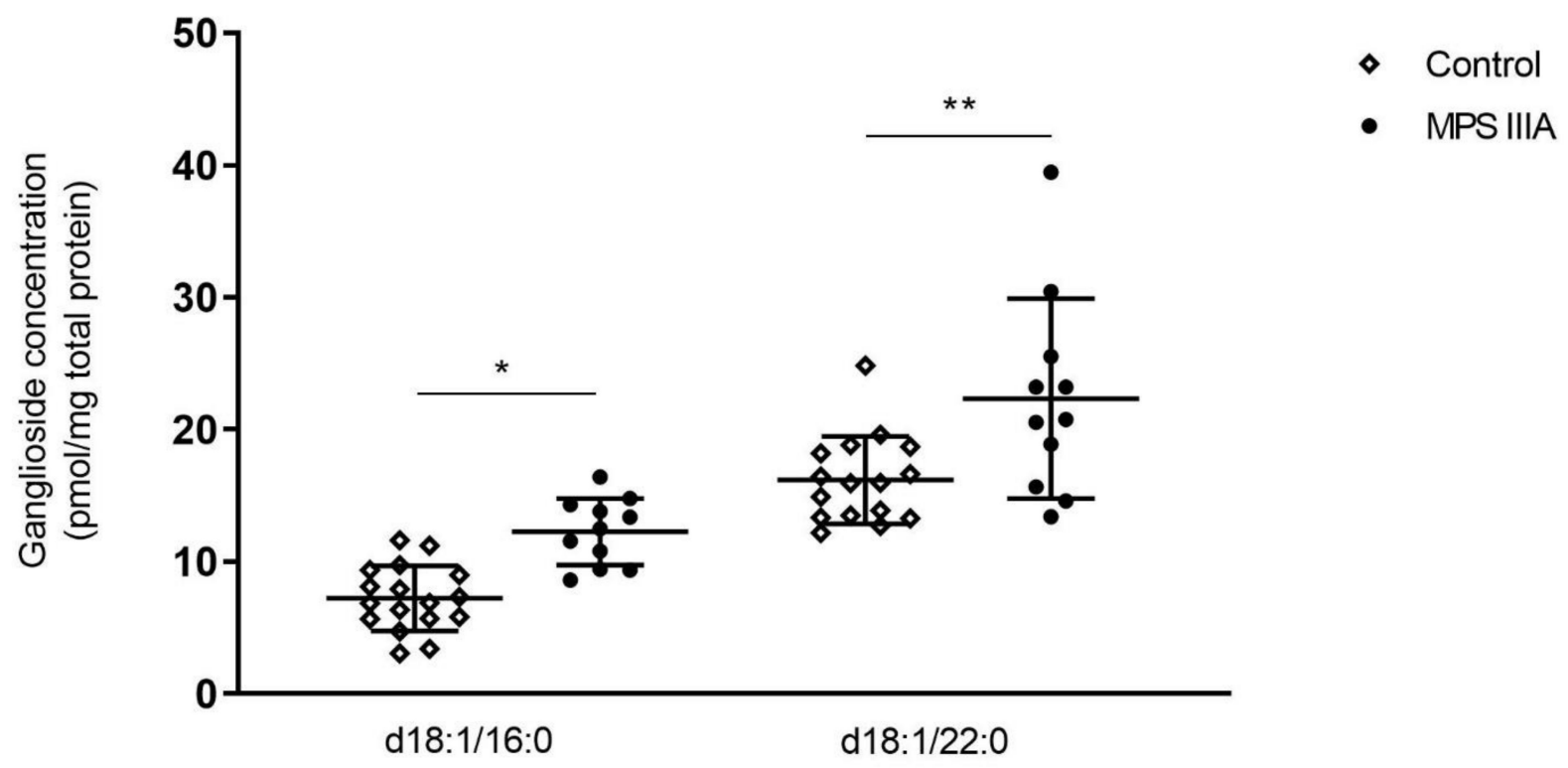

Figure 2. Ganglioside analysis. Ganglioside GM3 concentration in lung homogenates of 20-week control and MPS IIIA mice. Ganglioside GM3 was measured by LC MS/MS using an API 4000 QTrap mass spectrometer (ABSciex) coupled with a Prominence HPLC (Shimadzu). Data are expressed as ganglioside concentration ( $\mathrm{pmol} / \mathrm{mg}$ total protein) to the GM standard (GM1 (d35) d18:1/18:0) and plotted as mean \pm SD; two-tailed Students $t$-tests, * and ** indicate a significant difference between control and MPS IIIA mice, $p<0.0001$ and 0.0077 , respectively, $n=17$ control and 11 MPS IIIA samples. 


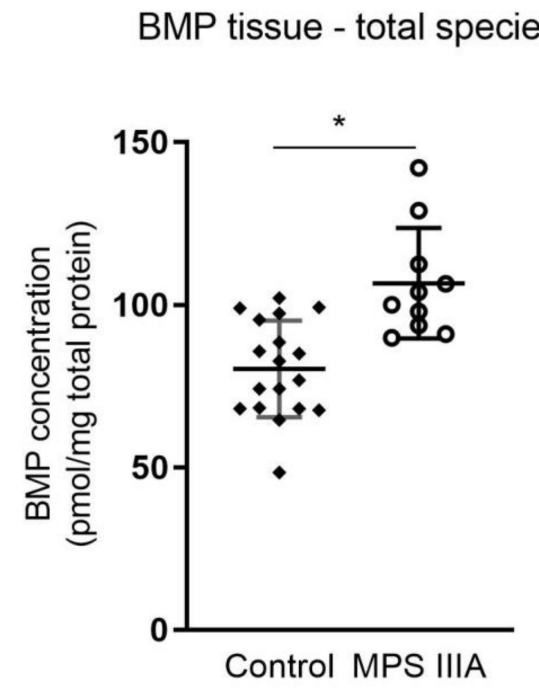

Figure 3. Total bis(monoacylglycerol)phosphate (BMP) analysis. Total BMP concentration in lung homogenates of 20-week control and MPS IIIA mice. Quantification of the BMP molecular species was measured by LC MS/MS using an API 4000 QTrap mass spectrometer (ABSciex) coupled with a Prominence HPLC (Shimadzu). Data are expressed as BMP concentration ( $\mathrm{pmol} / \mathrm{mg}$ total protein) to the BMP standard (BMP 14:0/14:0(Avanti 840445P)) and plotted as mean \pm SD; two-tailed Students $t$-test $*$ indicates a significant difference, $p=0.0002$, two-tailed Students $t$-test; $n=18$ control and 10 MPS IIIA samples.

BMP - tissue

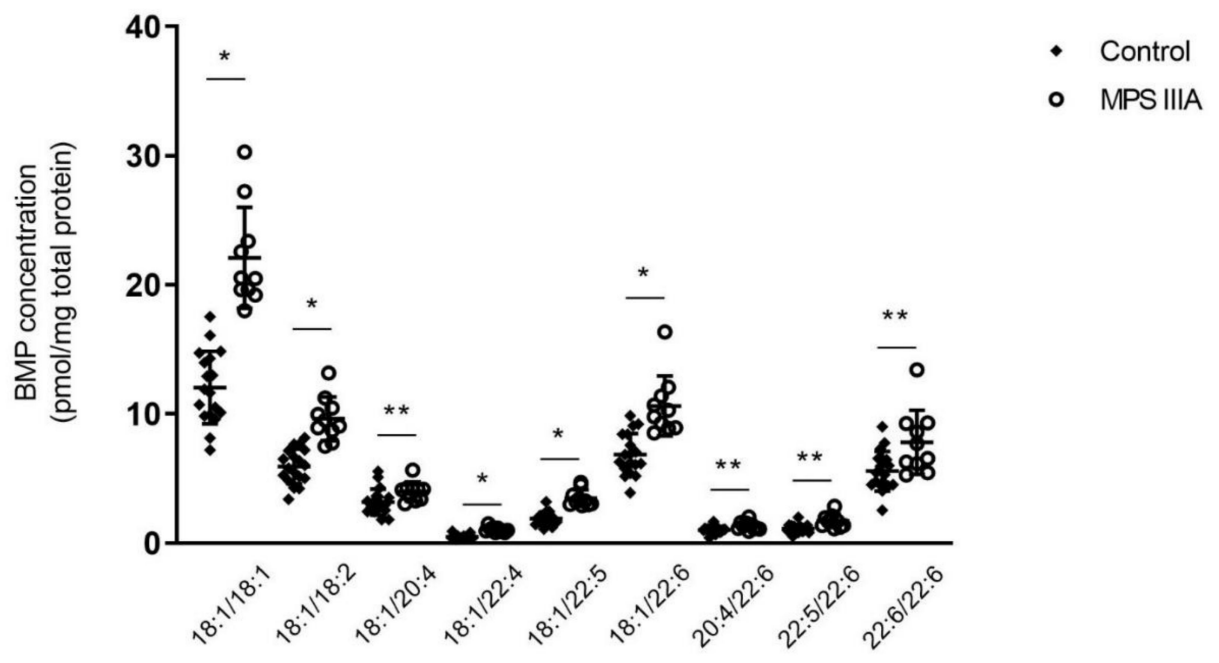

Figure 4. Bis(monoacylglycerol)phosphate (BMP) molecular species analysis. BMP molecular species concentration in lung homogenates of 20-week control and MPS IIIA mice. Quantification of the BMP molecular species was measured by LC MS/MS using an API 4000 QTrap mass spectrometer (ABSciex) coupled with a Prominence HPLC (Shimadzu). Data are expressed as BMP concentration ( $\mathrm{pmol} / \mathrm{mg}$ total protein) to the BMP standard (BMP 14:0/14:0(Avanti 840445P)) and plotted as mean \pm SD; two-tailed Students $t$-tests, ${ }^{*}$ and ${ }^{* *}$ indicate a significant difference, $p<0.0001$ and $<0.05$, respectively between control and MPS IIIA mice; $n=18$ control and 10 MPS IIIA samples.

There were no significant changes in the total amount of BMP measured in BALF of MPS IIIA mice when compared to control mice (Supplementary Materials-Table S3). However, further analysis of the subspecies of BMP showed significant decreases in three of seventeen molecular species examined when compared with control mice (Figure 5, Supplementary Materials-Table S3). 


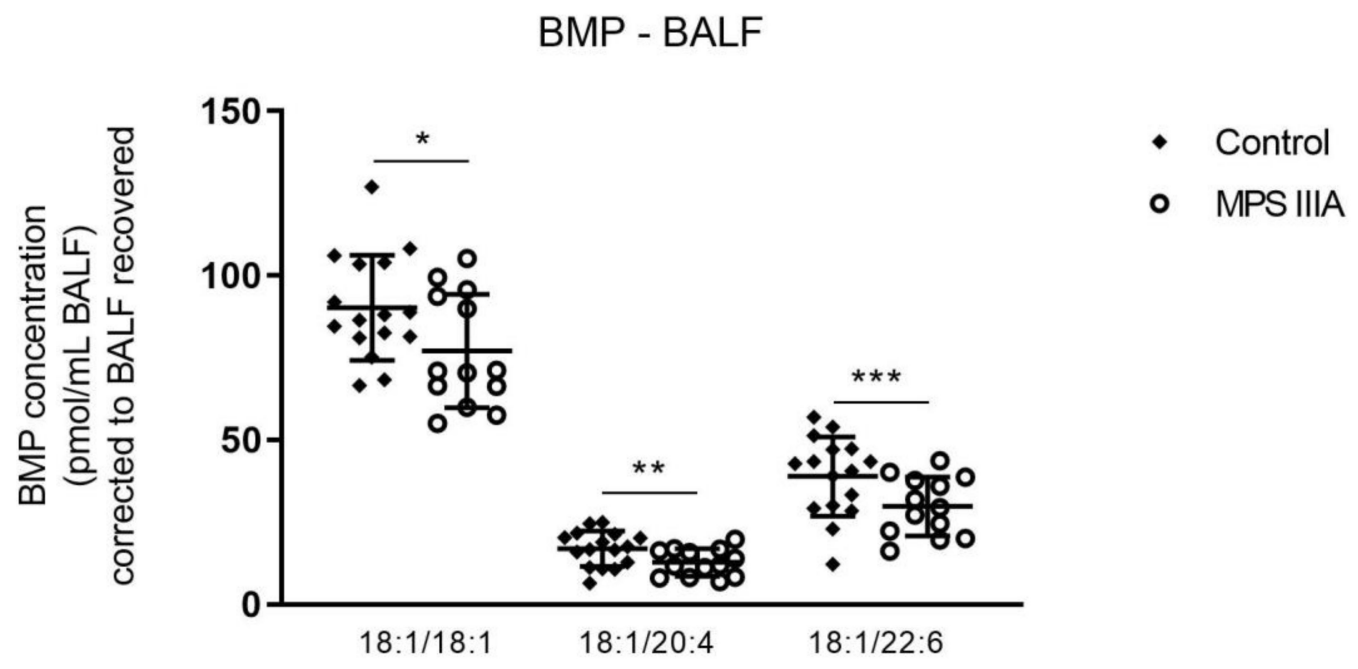

Figure 5. Bis(monoacylglycerol)phosphate (BMP) analysis of BALF. Quantification of the BMP molecular species in 20-week control and MPS IIIA BALF. BMP was measured by LC MS/MS using an API 4000 QTrap mass spectrometer (ABSciex) coupled with a Prominence HPLC (Shimadzu). Data are expressed as BMP concentration (pmol/mL BALF) to the BMP standard (BMP 14:0/14:0 (Avanti 840445P)) and plotted as mean \pm SD; two-tailed Students $t$-tests, ${ }^{*},{ }^{* *}$ and ${ }^{* * *}$ indicate a significant difference, $p=0.0430,0.0300$ and 0.0325 , respectively between control and MPS IIIA mice; $n=17$ control and 11 MPS IIIA samples.

\subsubsection{Alterations in Cholesterol Concentration in Lung Tissue and BALF}

Total cholesterol measured in lung homogenates of MPS IIIA mice showed no significant difference when compared with control mice (Supplementary Material-Table S3). Total cholesterol measured in BALF of MPS IIIA mice showed a significant decrease when compared with control mice (Figure 6A). The decrease in BALF was further analysed, showing no difference in free cholesterol (Supplementary Materials-Table S3) and a significant decrease in cholesteryl esters in four species when compared to control mice (Figure 6B).

\section{Cholesterol - BALF}

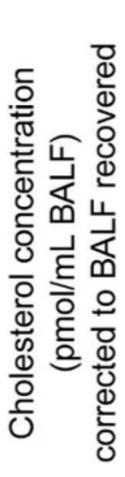

A

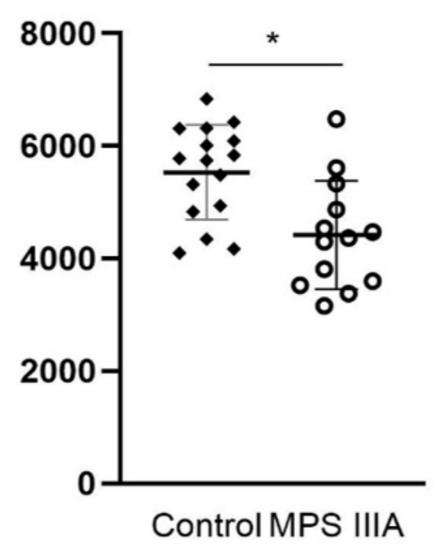

Figure 6. Cholesterol analysis of BALF (A) and cholesteryl ester analysis of BALF (B). Quantification of cholesterol and the ester molecular species in 20-week control and MPS IIIA BALF were measured by LC MS/MS using an API 4000 QTrap mass spectrometer (ABSciex) coupled with a Prominence HPLC (Shimadzu). Data are expressed as concentration (pmol/mL BALF) to C17 Cholesteryl ester (Sigma C5384) and plotted as mean \pm SD; two-tailed Students $t$-test, * indicates a significant difference, $p<0.0001$ between control and MPS IIIA mice, $n=16$ control and 13 MPS IIIA samples (A) and $n=15$ control and 13 MPS IIIA samples (B). 


\subsection{Phospholipid Composition and Alterations in Total Alveolar Phospholipid Pool Size}

Individual phospholipid headgroup components were measured in control and MPS IIIA BALF. The relative percentage of the individual major phospholipids, phosphatidylcholine and phosphatidylglycerol, and the minor phospholipids, phosphatidylserine and sphingomyelin, as a percentage of the total phospholipid pool remained unchanged (Supplementary Materials-Table S3). There was a small increase in the \% phosphatidylethanolamine (Supplementary Materials_-Table S3). Phosphatidylcholine (PC) molecular species composition (\% of total PL) was measured in BALF and lung tissue. Phosphatidylcholine molecular species composition remained unchanged in lung tissue (Supplementary Materials-Table S3); however, in BALF there was an increase and decrease in two different species, respectively (Supplementary Materials-Table S3). When all individual BALF phospholipid components were summed and expressed as nmol in the total lavage volume, there was a significant decrease of $\sim 50 \%$ in the total pool size of alveolar surfactant in MPS IIIA mice (Figure 7).

Total PL - BALF

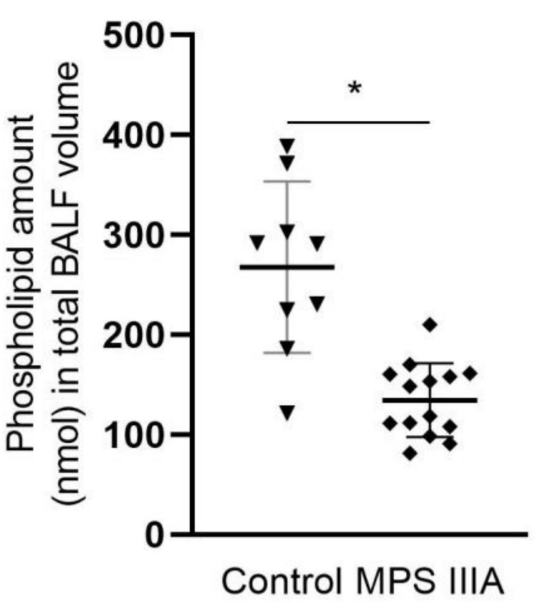

Figure 7. Total phospholipid pool size analysis in BALF. Quantification of the phospholipid species in control and MPS IIIA BALF. Phospholipids were measured using electrospray ionisation mass spectrometry (ESI-MS) (Waters XEVO TQ-MS). Data are expressed as total phospholipids (nmol) in the total corrected BALF volume and plotted as mean $\pm \mathrm{SD}$; two-tailed Students $t$-test, * indicates a significant difference, $p<0.0001$ between control and MPS IIIA mice; $n=9$ control and 14 MPS IIIA samples.

\subsection{Surfactant Protein Gene Expression and Protein Analysis}

There was a significant but modest decrease in the gene expression of SP-A, $-\mathrm{C}$ and -D in MPS IIIA lung tissue when compared to control tissue (Figure 8). A significant but modest decrease in the amount of SP-D protein was seen in MPS IIIA lung tissue but there was no change in the amount of SP-A, $-\mathrm{B}$ and $-\mathrm{C}$ (Figure 9). SP-A, $-\mathrm{C}$ and $-\mathrm{D}$ were significantly reduced in MPS IIIA BALF when compared to control BALF (Figure 10). 


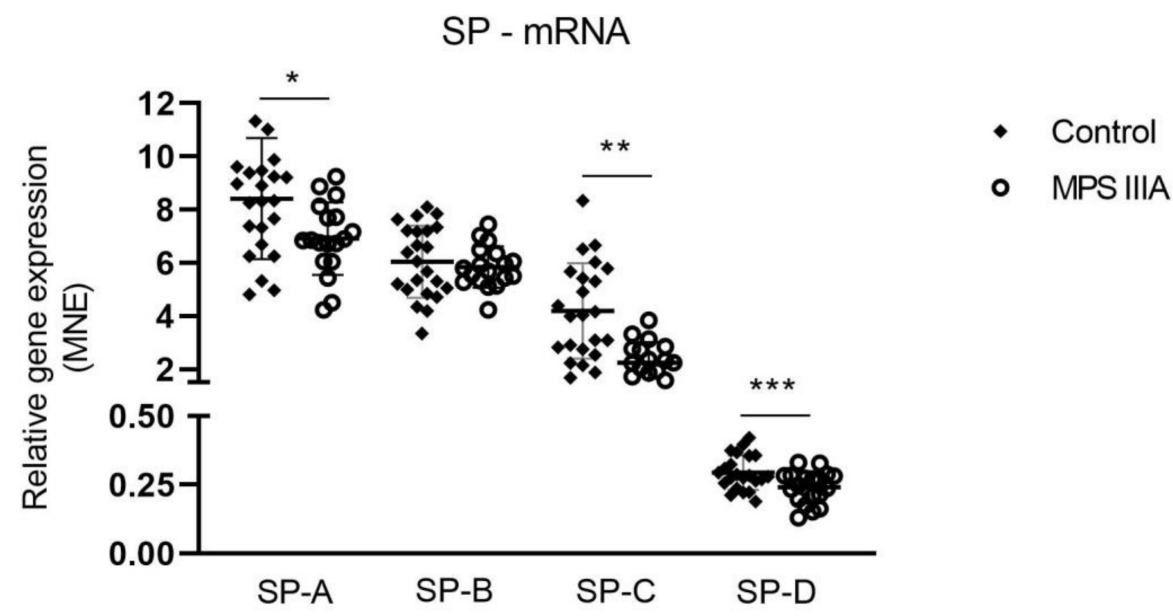

Figure 8. Mean normalised expression (MNE) of surfactant proteins -A, -B, -C and -D mRNA. Relative gene expression of surfactant proteins in control and MPS IIIA lung tissue. Data expressed as MNE and plotted as mean $\pm \mathrm{SD}$; two-tailed Students $t$-tests; ${ }^{*},{ }^{* *}$ and ${ }^{* * *}$ indicate significant differences $p=0.0184, p=0.0001$ and $p=0.0073$, respectively between control and MPS IIIA mice; $n=23$ control and 18-19 MPS IIIA samples.
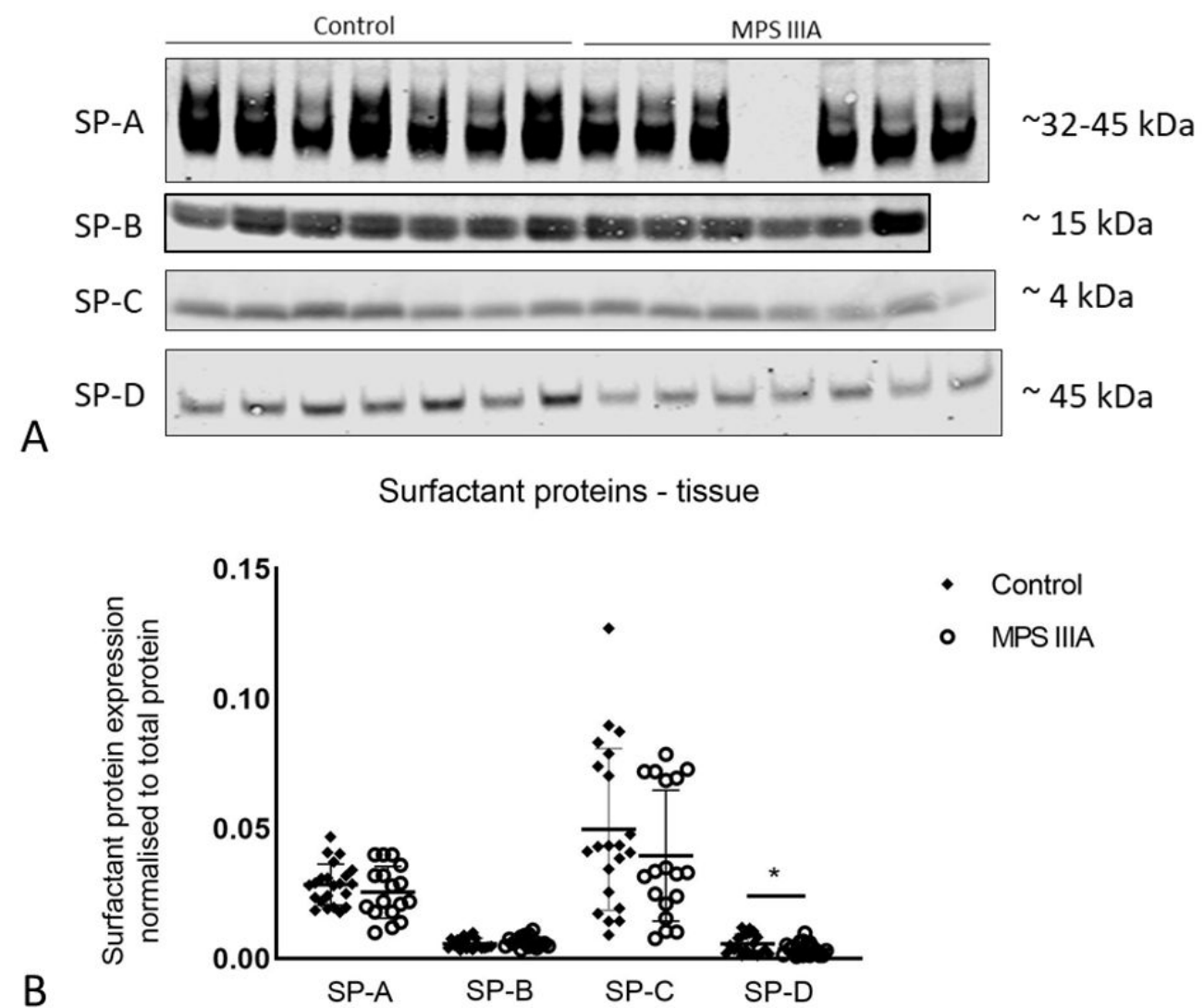

Figure 9. Protein expression of surfactant proteins -A, -B, -C and -D. (A) Representative Western blot images of part sets of control and MPS IIIA lung tissue samples probed for SP-A (primary antibody-rabbit Thermo Scientific PA5-76699), SP-B (primary antibody-rabbit SevenHills Bioreagents WRAB-48604), SP-C (primary antibody-rabbit SevenHills Bioreagents WRAB-MSPC) and SP-D (primary antibody-rabbit Chemicon AB3434). (B) Data normalised to total protein and presented as mean $\pm \mathrm{SD}$; two tailed Students $t$-tests, ${ }^{*}$ indicates a significant difference, $p=0.0443$ between control and MPS IIIA mice; $n=22$ control, 17 MPS IIIA (SP-A analysis); 20 control, 16 MPS IIIA (SP-B analysis); 21 control, 18 MPS IIIA (SP-C analysis) and 22 control, 19 MPS IIIA (SP-D analysis) samples. Entire band height of SP-A measured from 32-45 kDa [35]. 


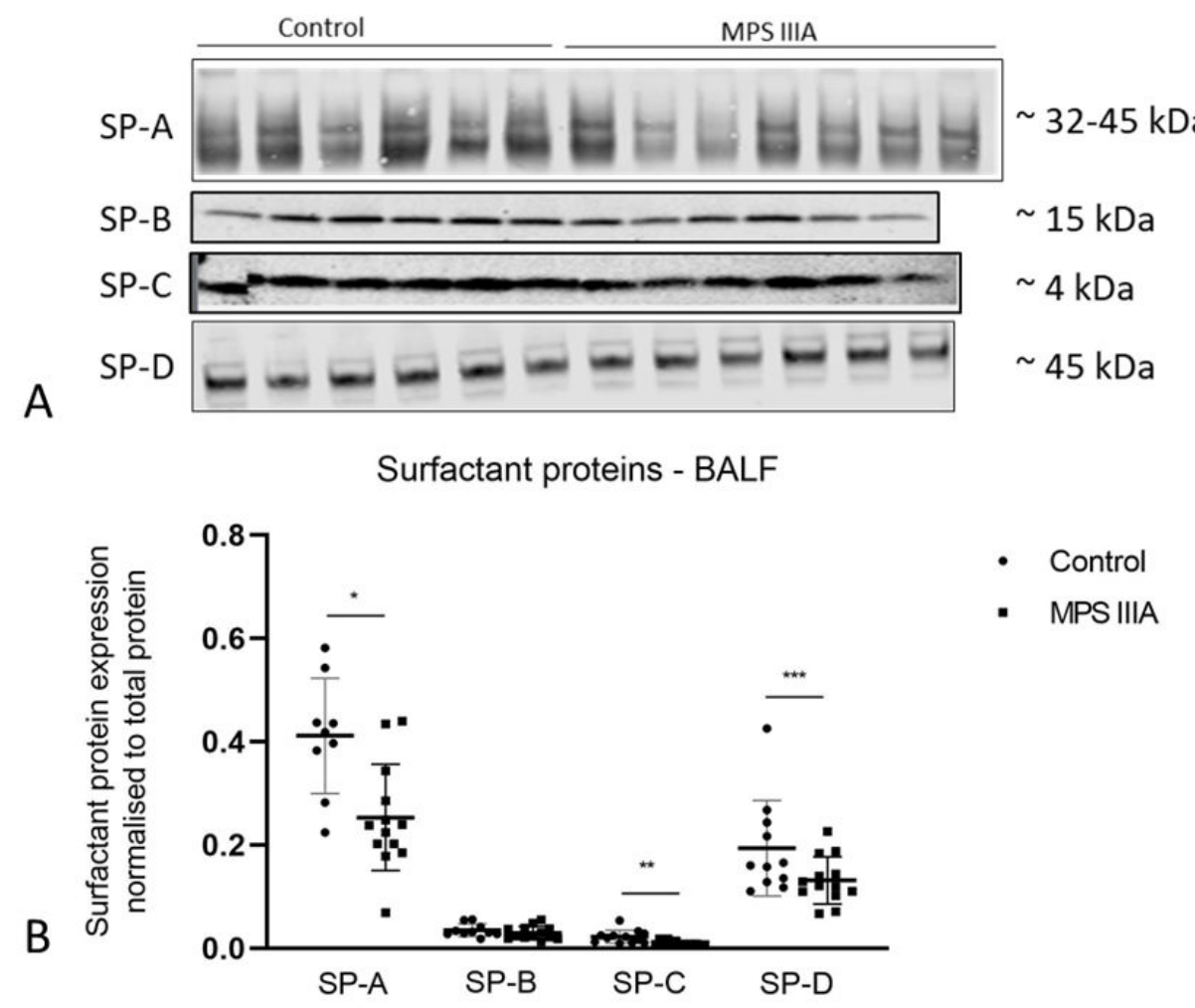

Figure 10. Protein expression of surfactant proteins -A, -B, -C and -D in BALF. (A) Representative Western blot images of part sets of SP-A, $-\mathrm{C}$ and -D samples pictured. Western blot analyses were performed with the following primary antibodies: SP-A (rabbit Thermo Scientific PA5-76695), SP-B (rabbit SevenHills Bioreagents WRAB-48604), SP-C (rabbit SevenHills Bioreagents WRAB-MSPC) and SP-D (rabbit Thermo Scientific PA5-51476). (B) Data normalised to total protein and presented as mean $\pm \mathrm{SD}$; significant differences are indicated ${ }^{*} p=0.0027,{ }^{* *} p=0.0024$ and ${ }^{* * *} p=0.0438$; two tailed Students $t$-test; $n=9$ control, 13 MPS IIIA (SP-A analysis); 10 control, 13 MPS IIIA (SP-B analysis); 12 control, 13 MPS IIIA (SP-C analysis) and 11 control, 13 MPS IIIA (SP-D analysis) samples. Entire band height of SP-A measured from 32-45 kDa [35].

\subsection{Captive Bubble Surfactometry}

Captive bubble surfactometry was used to measure the rate of film formation upon initial adsorption (Figure 11A) and immediately following a sudden bubble expansion (Figure 11B), each over $5 \mathrm{~min}$ at $37^{\circ} \mathrm{C}$. Under these static conditions, surfactant demonstrated similar initial adsorption between control and MPS IIIA samples, lowering equilibrium surface tension ( $\gamma$ eq) to $\sim 20 \mathrm{mN} / \mathrm{m}$ (Figure 11A). However, surfactant from MPS IIIA animals demonstrated a decreased post expansion adsorption rate compared to surfactant from control mice (Figure 11B). Under dynamic conditions (30 cycles/min) the biophysical behaviour of MPS IIIA surfactant was highly variable (Figure 12) relative to control samples, with the surfactant of many diseased individual animals performing more poorly. Upon averaging the individual variables, it was evident that MPS IIIA surfactant was unable to reach a low surface tension at minimum bubble size $\left(\gamma_{\min }\right)$ after 20 cycles (Figure 13A). Similarly, the surfactant of MPS IIIA animals also had a higher surface tension at maximum bubble size $\left(\gamma_{\max }\right)$ during dynamic cycling (Figure 13B). In addition, the change in area required to reach $\gamma_{\min }$ was significantly greater in MPS IIIA animals (Figure 13C). MPS IIIA samples also had higher compressibility (lower slopes) compared to control samples (Figure 13D), as well as an increased hysteresis (Figure 13E). 


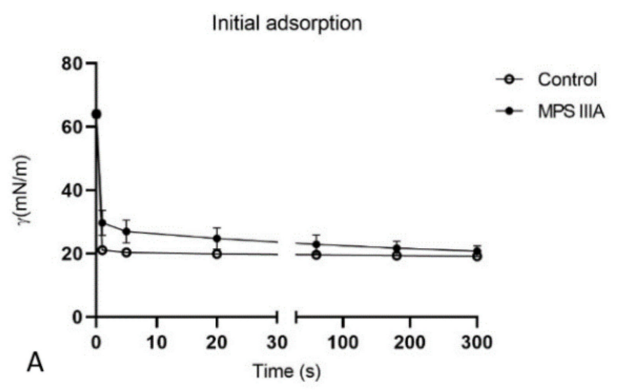

Post expansion adsorption

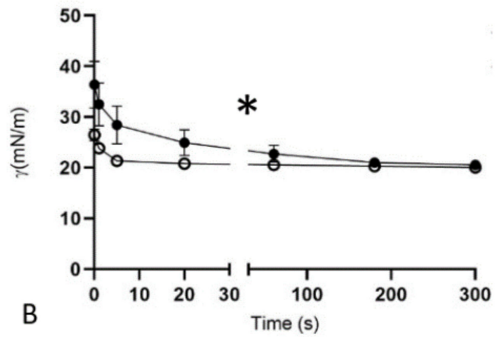

Figure 11. Captive bubble surfactometry of BALF samples under static conditions. Surfactant biophysical properties of control and MPS IIIA BALF under static conditions-initial adsorption (A) and post expansion adsorption (B). Data are expressed as $\gamma(\mathrm{m} / \mathrm{Nm})$ and plotted as mean $\pm \mathrm{SD}$; repeated measures ANOVA (A) $p<0.0001$ (time effect); (B) ${ }^{*} p=0.0253$ (disease effect), $p<0.0001$ (time effect) and there was an interaction between genotype and time; $n=10$ control and 6 MPS IIIA samples.

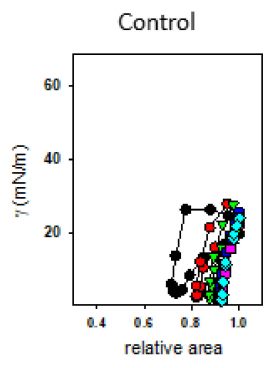

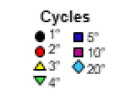
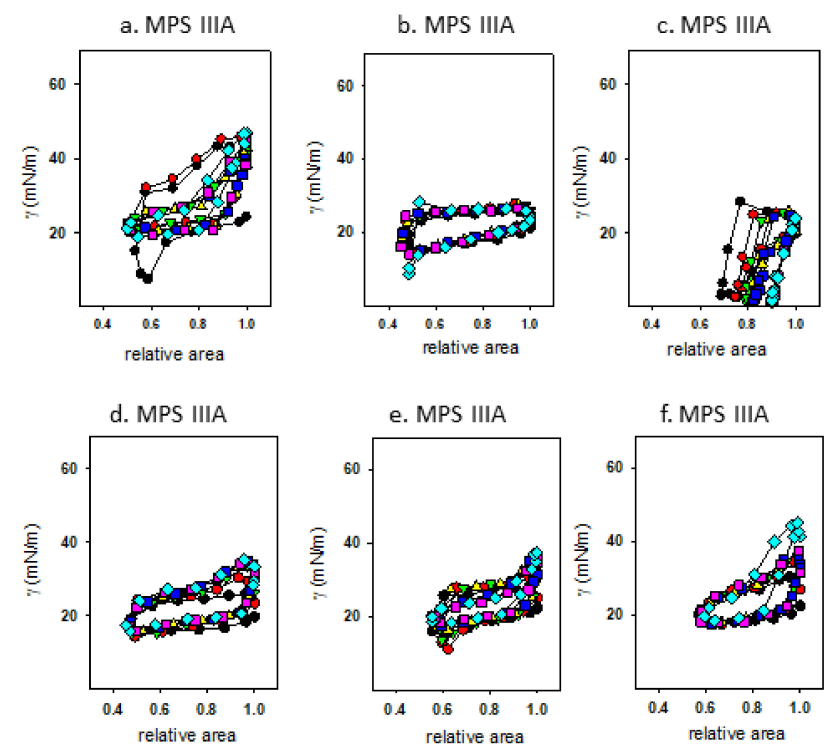

Figure 12. Captive bubble surfactometry of BALF surfactant samples under dynamic conditions. Biophysical properties of representative control and each individual MPS IIIA surfactant sample subjected to dynamic compression-expansion cycling which mimics spontaneous respiratory cycles. The lower limb of the curve represents the compression of the bubble, and the upper limb of the curve was obtained upon expansion. Thirty cycles were performed at 30 cycles per min with cycles 1, 2, 3, 4, 5, 10 and 20 shown. 


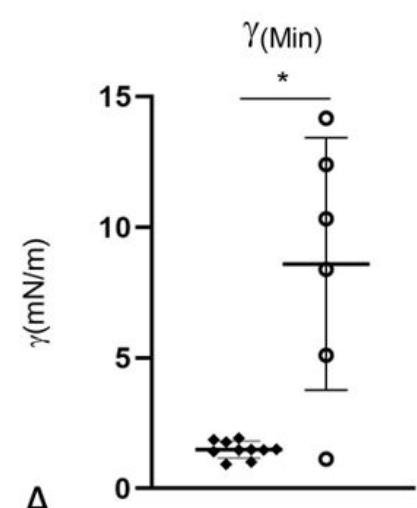

B

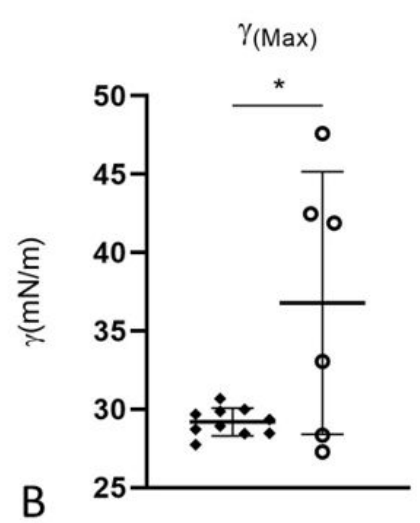

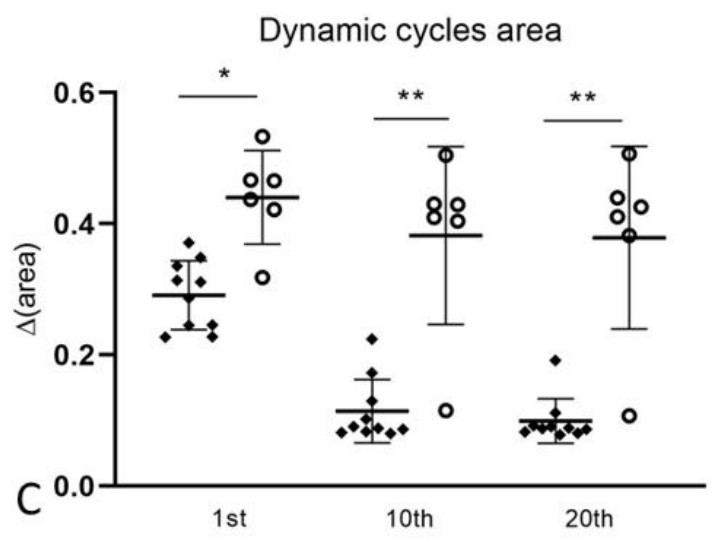
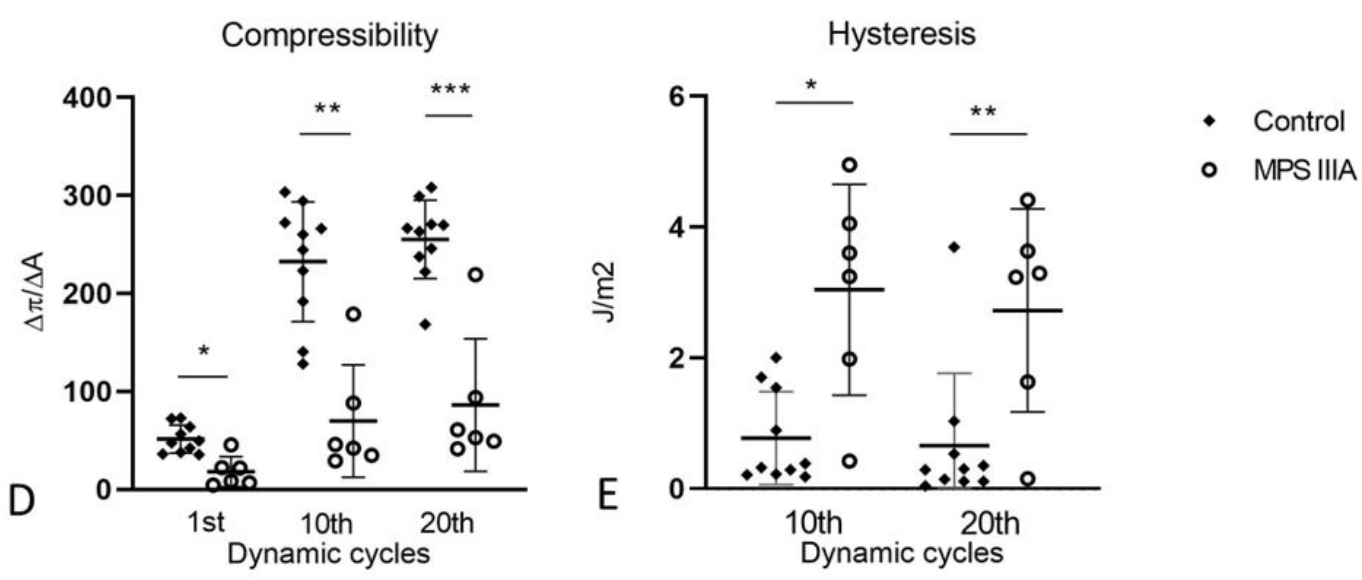

Figure 13. Biophysical properties of surfactant from BALF under dynamic compression cycling. Minimum (A) and maximum (B) surface tension of control and MPS IIIA BALF surfactant samples expressed as $\mathrm{mN} / \mathrm{m}$. MPS IIIA animals have higher minimum surface tension, $p<0.003$ (A), and higher maximum surface tension, $p<0.0115$ (B). (C) Relative area of compression required to reach $\gamma_{\min }$ was calculated as the percentage of area reduction needed to decrease the surface tension to the minimum value. Change in relative area in the 1st, 10th and 20th cycles was increased in MPS IIIA samples, ${ }^{*} p=0.0003,{ }^{* *} p<0.0001$. (D) Compressibility $(\Delta \mathrm{P} / \Delta \mathrm{A})$ was calculated as the slope value of the line passing through the minimum and maximum points of compression (minimum and maximum areas of the bubble) in the dynamic cycling curve (the steeper the slope, i.e., the higher the value, the lower the surfactant compressibility). ${ }^{*} p=0.0006,{ }^{* *} p=0.0001$, ${ }^{* * *} p<0.0001$. (E) Hysteresis was calculated as the enclosed area between the compression and expansion segments of the isotherms. ${ }^{*} p=0.0015,{ }^{* *} p=0.0076$. Data plotted as mean $\pm \mathrm{SD}$; two-tailed Students $t$-tests used for all analyses; $n=10$ control and 6 MPS IIIA samples.

\section{Discussion}

MPS IIIA, a lysosomal storage disease with predominantly neurological pathology, is characterised by the primary storage of HS, and secondary storage of gangliosides GM2 and GM3 and cholesterol in the brain [4]. Similar changes in the lung have the potential to impair the function of the alveolar epithelium, thereby leading to changes in surfactant lipid and protein metabolism and hence the surface activity of the mixture acting at the alveolar air-liquid interface. We propose that this alveolar pathology may impact the susceptibility of MPS IIIA patients to respiratory infections and other pulmonary insults.

We reported an increase in HS in both lung tissue and alveolar surfactant of MPS IIIA mice compared with unaffected control mice. We have also found increases in ganglioside GM3 and BMP lipid species, decreases in surfactant proteins -A, -C and -D mRNA expression and a decrease in SP-D protein in lung tissue. Analysis of alveolar surfactant has shown a decrease in BMP and cholesterol and decreases in surfactant proteins $-\mathrm{A},-\mathrm{C}$ and -D. Furthermore, although there were no major changes in the phospholipid composition of alveolar surfactant, there was a $49.7 \%$ decrease in the total phospholipid pool size in 
the MPS IIIA mouse lung. Even though the experimental phospholipid concentration was kept constant in vitro, MPS IIIA mice also demonstrated reduced surface activity upon dynamic compression-expansion cycling. This is the first study to have demonstrated an impairment of surfactant composition and function in the mucopolysaccharidoses.

\subsection{Heparan Sulphate Accumulation in Lung Tissue and the Alveolar Compartment}

The many roles of HS are well defined in mammalian tissue where it is expressed ubiquitously in the extracellular matrix (ECM) and basement membrane of tissues, and on cell surfaces $[36,37]$. Heparan sulphate is involved in many physiological processes including cell signalling, cell adhesion, inflammation and immunity [38-40]. The role extends to help modulate the homeostasis of the parenchymal tissue of the lung [40,41], acting as a key structural component to maintain the efficient architecture and functioning of the lung; i.e., for alveolar walls to be thin for appropriate gas exchange, firm to prevent collapse of the alveolus, flexible to cope with volume changes during breathing [41] and as a regulator of signalling pathways [42,43]. When the breakdown of HS is compromised, as in MPS IIIA, it pre-empts major disturbances in the coordination of not only effector molecules, including growth factors and signalling factors, but extends to proteases and ECM molecules inherently impacting the structural integrity of the lung [44-46]. However, the effects of HS within the alveolar compartment itself have to our knowledge not previously been investigated.

The HS results in this study using butanolysis followed by LC-MS/MS [20] have shown negligible differences in HS lung tissue content between heterozygous and wild type mice, but a significant increase in MPS IIIA mice, which is similar to the results reported for MPS IIIA mice in a previous study [47]. Furthermore, we report for the first time a significant increase in the content of HS in the BALF of MPS IIIA mice when compared with that of either wild type or heterozygous mice. The presence of undegraded HS in secreted alveolar surfactant may alter or impact the distribution and function of the interfacial surfactant film components. It is possible that this excess substrate may have a similar impact as bacterial lipopolysaccharide (LPS), which is a major outer surface membrane component present in almost all Gram-negative bacteria, and that is capable of incorporating into the surfactant monolayer [48]. This destabilises the interfacial film and inactivates surfactant, therefore disrupting the ability of surfactant to regulate alveolar surface tension $[48,49]$. Alternatively, it may be possible that the anionic character of the HS polymer may affect the organisation of surfactant, for example by interacting with the cationic hydrophobic proteins, potentially limiting their availability to carry out their biophysical function. Certainly, our surface activity results support the suggestion that the accumulation of alveolar HS affects the organisation and/or behaviour of the surfactant film, therefore impeding its biophysical function and reducing surface activity. It is also worth considering that surfactant function can be inhibited or inactivated through the presence of other factors such as serum proteins [50], proteases, reactive oxygen and nitrogen species or as a consequence of acute lung injury or inflammation [51-53]. While pulmonary inflammation has not yet been investigated there is evidence of neural and systemic inflammation in MPS IIIA mice [54,55].

\subsection{The Role of Pulmonary Surfactant}

Pulmonary surfactant consists predominantly of phospholipids, the most abundant of which is dipalmitoylphosphatidylcholine (DPPC), other unsaturated phosphatidylcholine (PC) species, phosphatidylglycerol, phosphatidylinositol and other minor phospholipids, sphingomyelin and BMP, along with neutral lipids and cholesterol, triglycerides and free fatty acids. Together the phospholipids contribute $>90 \%$ of pulmonary surfactant composition, with the remaining approximately $8 \%$ consisting of surfactant proteins $-\mathrm{A},-\mathrm{B}$, $-C$ and $-D$ [56]. Surfactant proteins $-B$ and $-C$ combine with phospho- and neutral lipids to provide structural integrity to the interfacial film whilst surfactant proteins -A and -D play an important role in innate immune function [57]. The unique structure of the surfactant 
lipo-protein film is essential to reduce the work of breathing by maintaining a sufficiently low alveolar surface tension and increasing lung compliance [49]. This lipid-rich mixture is synthesised in the alveolar epithelial type II cell and stored within lamellar bodies, which are modified lysosomes. In response to physical and chemical stimuli, lamellar bodies are exocytosed into the fluid lining of the alveoli, where they swell and unravel to form a membrane-based network from which the multi-layered pulmonary surfactant surface film is derived [58]. Regulation of the interfacial surface tension is achieved as the lipids adsorb to the air-liquid interface to form a surface-active film that lowers the surface tension. Given the biosynthetic origin of lamellar bodies, coupled with evidence of increased accumulation of HS in both tissue and BALF and of disruption to lipid synthesis leading to secondary lipid storage, we propose that there will be downstream effects on the surfactant system that may impact pulmonary surfactant function.

\subsection{Alterations in Gangliosides, BMP and Cholesterol Composition}

Gangliosides are acidic glycosphingolipids that contain one or more sialic acids [59] and are primarily regarded as neuronal material, with previous studies having shown an elevation of the gangliosides GM2 and GM3 in the brain of MPS IIIA mice [60] and very low expression in the healthy adult lung [61]. In mouse neuronal tissue GM3 appears to be co-localised with cholesterol and other glycosphingolipids in specialised lipid rafts $[62,63]$. For example, GM3 inhibits EGFR-tyrosine kinase to differing degrees depending on its sialic acid species. GM2 was below the level of quantitation in mouse lung tissue in this study, which is consistent with the findings of a recent mouse lung lipidomics study [61]. A significant increase in two of the subspecies of GM3 in MPS IIIA mouse lung tissue was recorded when compared with the control group. As well as being involved in the regulation of numerous cell biological events, including development, trafficking, signalling and cellular interactions, GM3 performs an anti-inflammation role. Studies of GM3 deficient mice reveal an exacerbation in inflammatory pathways in rheumatoid arthritis $[63,64]$. Gaucher disease is associated with increased insulin resistance and has evidence of increased GM3 concentrations in human plasma, although it is unknown if GM3 has any direct effect on inflammatory pathways in this disease [65-67]. There is also evidence of elevated levels of GM3 in mouse cerebellar brain cells in juvenile neuronal ceroid lipofuscinosis but the effect of this has not been determined [65]. There has been no evidence to suggest that GM3 in the lung is affected in either disease. The precise role of GM3 in lung tissue remains largely unknown [61].

The specific function of BMP in the lung is also largely unknown. However, in general it plays a significant role in cholesterol distribution $[68,69]$ through the formation of lipid rafts, cell signalling and multivesicular body and small vesicle formation [70,71] in the late endosome-lysosome compartments of the cell. It is a structural isomer of phosphatidylglycerol and is most abundant in the endosome-lysosome system of the cell and generally localised to the membranes of multivesicular bodies [72]. BMP is negatively charged, facilitating the adhesion of soluble positively charged hydrolases and activator proteins, allowing them to degrade substrates at the inner membranes of the lysosome [72]. Thus, BMP has an important role in the regulation of lipid and membrane dynamics in the endosome-lysosome system and an excess of BMP may impair the sorting and dissociation of lysosomal hydrolase complex which affects downstream degradation processes [73]. We have reported for the first time an accumulation of BMP in MPS IIIA lung tissue, and a significant decrease in some BMP species within the alveolar compartment. The implications of the decrease in BMP and its function in surfactant are not entirely known, but our surface activity results suggest that the fluidity of the pulmonary surfactant film may be affected, potentially impairing normal function.

Cholesterol is an essential component of all cell membranes of all tissues, including lung tissue, and a critical modulator of pulmonary surfactant [72,74]. In combination with surfactant proteins $-\mathrm{B}$ and $-\mathrm{C}$, cholesterol is embedded into the lipid bilayers of pulmonary surfactant thereby increasing the viscosity of the membrane [75], enabling 
pulmonary surfactant to reduce the work of breathing by stabilising alveolar surface tension and increasing lung compliance. Fluidity and viscosity must adjust rapidly in response to inspiration and expiration, relying on the properties of cholesterol to optimise the ordered surfactant film to recover quickly from disruption [75-77]. Without cholesterol, the lipid bilayer of pulmonary surfactant is disordered and results in compromised surface tension increasing the work of breathing $[76,77]$. Cholesterol levels are tightly regulated by transcriptional regulation of cholesterol biosynthesis and cellular uptake as well as by deposition of cholesterol into fat droplets in an esterified form; a type of storage [78]. We have found a significant decrease in total cholesterol in MPS IIIA BALF when compared with control samples. Interestingly, this was driven by a significant decrease in cholesteryl esters (CE) as there was no change in free cholesterol. Cholesteryl esters consist of a free cholesterol unit covalently linked to a long chain fatty acid rendering them more hydrophobic than free cholesterol. They reside in the surface-associated surfactant reservoir to be hydrolysed to enable adsorption of cholesterol to the surface-active layer $[79,80]$. Therefore, the reduction in CE may reduce the effectiveness of pulmonary surfactant, as well as affecting the availability for recruitment and distribution of free cholesterol into the film. A physiological level of cholesterol is required to promote the optimal level of adsorption of surfactant as both an overabundance and a reduction of cholesterol can inhibit surfactant adsorption [81]. The potential reduction in cholesterol availability suggested by our study may be reflected in the impaired surface activity we observed.

\subsection{Total Alveolar Phospholipid Pool}

For the pulmonary surfactant film to decrease surface tension it must be packed efficiently and maintain interfacial integrity so that during expiration the film is compressed to reduce surface tension to close to $0 \mathrm{mN} / \mathrm{m}$. During inspiration and expansion the surfaceactive film recruits additional surface-active molecules from the aqueous hypophase [56,82]. The phospholipid pool must have a high turnover to maintain its size and quality as it is decreased by the degradation, oxidation and recycling at the air-liquid interface and refreshed by the secretion of surfactant stored in lamellar bodies [83]. The process of fusion of the lamellar bodies with the cell membrane, exocytosis of surfactant and formation of the surfactant film is a fundamental and lengthy process (seconds to minutes) when compared with endocytic functioning in other cells (milliseconds) [84,85]. Hence, a substantial phospholipid pool size and high turnover are essential to maintain the integrity of the surfactant film during the dynamic breathing process. A significant $\sim 50 \%$ reduction in the total phospholipid pool was evident in MPS IIIA BALF when compared to control BALF. The surfactant proteins aid in the regulation of phospholipid pool size. Surfactant protein -A and -C promote the movement of surfactant phospholipids to the surfactant film [86,87], while surfactant proteins -B and -D have significant roles in maintaining surfactant pool sizes, with SP-D deficient mice demonstrating altered surfactant morphology [88-93]. The decrease in the phospholipid pool in MPS IIIA mice described here may have a significant impact on the function of pulmonary surfactant. Specifically, the phospholipid pool reduction may be detrimental to film integrity, and there may be further impairments to the film coupled with the reductions of the surfactant proteins compromising the ability to maintain and regulate the pool size.

\subsection{Surfactant Proteins A-D}

Surfactant proteins are synthesised by the alveolar epithelial type II cells where SP-B and $-\mathrm{C}$ are transported as they are progressively processed from larger precursors and packaged together with phospholipids from the endoplasmic reticulum to lamellar bodies by way of multivesicular bodies [94] before being secreted into the alveolar space. Surfactant proteins -A and -D are post-translationally modified in the endoplasmic reticulum and Golgi apparatus prior to being constitutively secreted to the hypophase $[25,95]$ to aid in the formation of the highly flexible surfactant film. SP-B in the MPS IIIA mouse was the only surfactant protein maintained at a constant level, which likely reflects SP-B's 
vital role in surfactant metabolism and function as evidenced by the fact that an SP-B null mutation is incompatible with life [96]. Conversely, the gene expression of the smaller hydrophobic protein, SP-C was reduced as was the amount of protein in BALF. SP-B and SP-C work closely together to modulate the lipid packing and spreading of the surfactant film to optimise the surface tension of the film during the respiratory cycle. However, while SP-B is critical to life, there is less dependence on SP-C in maintaining surfactant integrity as its levels can fluctuate without compromising function [97]. Functionality of the surfactant film is sustained in part due to SP-C in combination with cholesterol by inducing phase segregation into fluid ordered and fluid disordered sections up to a temperature of $37.5^{\circ} \mathrm{C}[75,77,98]$. SP-C enhances the expression of genes responsible for the metabolism and transport of cholesterol, therefore indirectly playing a role in modulating surfactant fluidity at physiological temperatures [75,99], but SP-C does not affect the phospholipid pool size [100]. Decreased SP-C may also have a deleterious effect on the structure of the septal wall in the ageing lung. Such structural changes are often the precursor to interstitial fibrosis that affects pulmonary mechanics $[99,101]$. SP-C also contributes to innate host defence in the pulmonary film, enhancing macrophage-mediated phagocytosis and clearance and limiting pulmonary inflammatory responses [99,102]. Deficiencies in SP-C are associated with severe respiratory pathologies [100,103-106] particularly in interstitial lung diseases in young children [107]. A concomitant reduction in both cholesterol and SP-C at the alveolar surface of MPS IIIA mice has the potential for a significant deleterious effect on the functioning of pulmonary surfactant by increasing the work of breathing and affecting host defence.

The larger surfactant proteins -A and -D are members of the collectin family of proteins and are integral to pulmonary innate immunity by interacting with immune cells, enhancing phagocytosis and killing by macrophages and neutrophils (for review see $[35,57,108-110])$. The reduction in the gene expression of SP-A and -D, the expression of SP-D protein in mouse lung tissue, and the amount of SP-A and -D in BALF, suggest that innate immunity would likely be compromised in the MPS IIIA mouse. As well as their role in innate immunity, SP-A and -D are integral in forming the interfacial surfactant film. Deletion of SP-A affects the adsorption of pulmonary surfactant to the interface and the formation of tubular myelin in the hypophase, hence compromising the integrity of the pulmonary surfactant film [111,112]. Furthermore, SP-D plays a role in regulating the surfactant pool size and ultrastructure of the pulmonary surfactant lining of the lung, with evidence of SP-D deficient mice showing an accumulation of surfactant phospholipids, but no change in surfactant proteins [85,89-91]. Interestingly, the alveolar epithelial type II cells of SP-D deficient mice contain giant disorganised lamellar bodies and simultaneously there is an increase in the phospholipid pool size and the appearance and number of foamy alveolar macrophages $[89,93]$. The re-introduction of SP-D corrects the alveolar macrophage changes [113], strongly suggesting that SP-D plays a significant role in the correct internalisation and recycling of spent surfactant. Hence, SP-A and -D play significant roles in the metabolism, formation of surface-active interfacial film and innate immunity, and therefore the reduced gene and protein expression will likely have a detrimental impact on pulmonary surfactant formation and the innate immune system in the alveolar compartment of the MPS IIIA mouse.

\subsection{Surfactant Activity}

The ability of the surfactant film to adsorb to the air-liquid interface, as it is expanded and compressed during the breathing cycles, is measured in vitro using captive bubble surfactometry (CBS). Pulmonary surfactant, adsorbed at the air-liquid interface, reduces surface tension $(\gamma)$ from $70 \mathrm{mN} / \mathrm{m}$ (at $37^{\circ} \mathrm{C}$ ) to $20-25 \mathrm{mN} / \mathrm{m}$ (equilibrium surface tension, $\left.\gamma_{\mathrm{eq}}\right)$ and then decreases further upon expiration to values of less than $2 \mathrm{mN} / \mathrm{m}$ [114]. Under static conditions, surfactant from MPS IIIA mice was able to reach the same equilibrium surface tension upon both initial adsorption and following post-expansion adsorption compared with that from control mice. However, the rate of surface tension reduction was 
slightly reduced in the post expansion adsorption maneuver, suggesting that there may be inhibitors present in the BALF preventing efficient recruitment and adsorption of new material to the expanding surface in order to rapidly reduce surface tension. Furthermore, upon dynamic cycling surfactant from MPS IIIA mice demonstrated significant increases in both $\gamma_{\min }$ and $\gamma_{\max }$, further supporting the suggestion that surfactant activity was inhibited in the diseased mice. The findings of compromised surfactant activity were further supported by the increase in compressibility $(\Delta \Pi / \Delta \mathrm{A})$ (a low compressibility, i.e., a steeper slope indicates improved efficiency of surfactant to reduce surface tension upon compression), and increased hysteresis (an indirect measure of the work associated with surfactant reorganising itself at the air-liquid interface during compression-expansion cycles). These changes indicate that the surfactant film is not able to pack as tightly on the compression cycle in the MPS IIIA mice when compared to control mice, likely as a consequence of the inclusion of spurious components into the films. Energy efficient surfactant films have a low hysteresis, which is calculated as the area enclosed between the compression and expansion moieties of the isotherms [56]. However, the surfactant from MPS IIIA mice had a higher hysteresis, indicating that it required significantly more energy to decrease the surface tension to a minimum level in the dynamic cycles.

Although surfactant from MPS IIIA mice had reduced surfactant phospholipids and proteins, these factors are unlikely to explain the differences observed in surface activity. We adjusted the quantity of surfactant added to the CBS to maintain a consistent amount of total phospholipid. Because the surfactant proteins were similarly reduced in the MPS IIIA samples the composition of the analysed surfactant is not likely to have differed between control and MPS IIIA samples. Therefore, we propose that the likely contaminating factor that may be inhibiting surface activity is HS or some derivatives thereof, which increased 25 -fold in BALF of MPS IIIA mice. The incorporation of macromolecules such as proteins and polysaccharides into the surfactant film has been shown to inhibit surface activity in vitro and in vivo as seen in acute respiratory distress syndrome [53,115-117]. However, the specific effect of HS on surface activity is unknown. Given that MPS IIIA patients are characterised by both neuro- and systemic inflammation [118], we cannot discount the possibility that there may also be other contaminating factors such as cytokines, e.g., C-reactive protein and other amine, peptide and lipid inflammatory mediators, which have also been shown to be potent inhibitors of surfactant [50,51]. Finally, the combination of both reduced surfactant quantities and reduced surface activity are likely to have highly detrimental effects on surfactant and lung function in MPS IIIA. Specifically, the higher surface tension and increased hysteresis in MPS IIIA surfactant during dynamic cycling indicate that expansion and compression cycles require more energy, potentially increasing the work of breathing $[112,114,119]$.

\section{Conclusions}

We have described increased storage of HS, GM3 and BMP in MPS IIIA mouse lung tissue. Combined with decreased gene and protein expression of surfactant proteins, this demonstrates altered pulmonary surfactant synthesis in MPS IIIA mice. We have also described an increase in HS as an exogenous contaminant in alveolar surfactant. At the same time there was a decrease in BMP, cholesterol, total phospholipids and surfactant proteins $-\mathrm{A},-\mathrm{C}$ and $-\mathrm{D}$ in MPS IIIA alveolar surfactant, suggesting impaired secretion. Collectively these changes have contributed to a decrease in surface activity, which is likely to impact lung mechanics. The reduction, particularly in SP-A and SP-D, is also likely to negatively affect pulmonary innate immunity. This mouse model of Sanfilippo syndrome has, for the first time in any mucopolysaccharidosis, shown alterations in pulmonary surfactant contributing to respiratory dysfunction in the distal lung.

Supplementary Materials: The following are available online at https:/ / www.mdpi.com/article/10 .3390/cells10040849/s1. 
Author Contributions: Conceptualisation, E.J.P.-L., S.O. and T.L.P.; methodology, E.J.P.-L., S.O., T.L.P., P.J.T., C.A., M.H.P., M.E., M.F.S., A.D.P., J.P.-G., J.L.M.; software, T.L.P., C.A., G.K., M.F.S.; validation and formal analysis, T.L.P., S.O., P.J.T., C.A., M.H.P. and G.K.; investigation, T.L.P., S.O., E.J.P.-L., P.J.T., M.F.S., C.A., M.H.P., G.K., M.E., A.D.P., J.L.M., J.P.-G.; resources, E.J.P.-L., S.O., M.F.S., J.L.M., J.P.-G. and A.D.P.; writing-original draft preparation, T.L.P.; writing-review and editing, E.J.P.-L. and S.O.; supervision, E.J.P.-L., S.O., P.J.T. project administration S.O.; funding acquisition S.O., E.J.P.-L., T.L.P. All authors have read and agreed to the published version of the manuscript.

Funding: Sansom Institute for Health Research Grant (SO and EPL), Research Training Program Fee Offset Scholarship (TP), Commonwealth Scholarships for South Australia Program (TP), Spanish Ministry of Science and Innovation and Regional Government of Madrid (C.A., M.E. and J.P.-G.).

Institutional Review Board Statement: The study was conducted according to the guidelines of the Australian Code for the care and use of animals for scientific purposes, and approved by the Animal Ethics Committee of the Women's \& Children's Health Network (\#AE1054 approved 6 December 2016 and \# AEC1031/12/18 approved 18 April 2016).

Informed Consent Statement: Not applicable.

Data Availability Statement: The data presented in this study are available in this article and the associated supplementary material, i.e., Table S3.

Acknowledgments: The authors wish to thank Kim Hemsley and Adeline Lau for providing mice for the scavenge protocol from their MPS IIIA colony that were excess to requirements and to Sarah Tamang for assistance with animal maintenance. They thank Megan Quinn and Stacey Holman for assistance with RNA analysis and Alicia Benavente for assistance with sample preparation for captive bubble surfactometry.

Conflicts of Interest: The authors declare no conflict of interest.

\section{References}

1. Cox, T.; Cachon-Gonzalez, M.B. The cellular pathology of lysosomal diseases. J. Pathol. 2012, 226, 241-254. [CrossRef]

2. Valstar, M.J.; Marchal, J.P.; Grootenhuis, M.; Colland, V.; Wijburg, F.A. Cognitive development in patients with Mucopolysaccharidosis type III (Sanfilippo syndrome). Orphanet J. Rare Dis. 2011, 6, 43. [CrossRef]

3. Valstar, M.; Ruijter, G.; Van Diggelen, O.; Poorthuis, B.; Wijburg, F. Sanfilippo syndrome: A mini-review. J. Inherit. Metab. Dis. 2008, 31, 240-252. [CrossRef]

4. Neufeld, E.; Meunzer, J. The metabolic and molecular bases of inherited disease (Scriver, C.R., Beaudet, A.L., Sly, W.S., Valle, D., Childs, B., Kinzler, K.W., and Vogelstein, B. eds. 8th edn. Biochemistry 2001, 67, 611-612.

5. Chiang, J.; Raiman, J.; Cutz, E.; Solomon, M.; Dell, S. Tachypnea of infancy as the first sign of Sanfilippo syndrome. Pediatrics 2014, 134, e884-e888. [CrossRef]

6. Cleary, M.A.; Wraith, J.E. Management of mucopolysaccharidosis type III. Arch. Dis. Child. 1993, 69, 403-406. [CrossRef]

7. Simonaro, C.M.; Guo, N.; DeAngelis, V.; Tomatsu, S.; Schuchman, E.H. Evaluation of pentosan polysulfate in mucopolysaccharidosis type IIIA mice. Mol. Genet. Metab. 2017, 120, S123. [CrossRef]

8. Leighton, S.; Papsin, B.; Vellodi, A.; Dinwiddie, R.; Lane, R. Disordered breathing during sleep in patients with mucopolysaccharidoses. Int. J. Pediatric Otorhinolaryngol. 2001, 58, 127-138. [CrossRef]

9. Lavery, C.; Hendriksz, C.J.; Jones, S.A. Mortality in patients with Sanfilippo syndrome. Orphanet J. Rare Dis. 2017, 12, 168. [CrossRef]

10. Meyer, A.; Kossow, K.; Gal, A.; Mühlhausen, C.; Ullrich, K.; Braulke, T.; Muschol, N. Scoring evaluation of the natural course of Mucopolysaccharidosis Type IIIA (Sanfilippo Syndrome Type A). Pediatrics 2007, 120, e1255-e1261. [CrossRef]

11. Mühlebach, M.S.; Wooten, W.; Muenzer, J. Respiratory manifestations in mucopolysaccharidoses. Paediatr. Respir. Rev. 2011, 12, 133-138. [CrossRef]

12. Bush, D.; Sremba, L.; Lomax, K.; Lipsett, J.; Ketteridge, D.; Bratkovic, D.; Eachautegul-Colon, Y.; Welsfeld-Adams, J.; Galambos, C.; Lummus, S.; et al. Neonatal onset interstitial lung disease as a primary presenting manifestation of mucopolysaccharidosis type I. J. Inherit. Metab. Dis. Rep. 2018, 43, 71-77.

13. Kurolap, A.; del Toro, M.; Spiegel, R.; Gutstein, A.; Shafir, G.; Cohen, I.J.; Barrabés, J.A.; Feldman, H.B. Gaucher disease type 3c: New patients with unique presentations and review of the literature. Mol. Genet. Metab. 2019, 127, 138-146. [CrossRef]

14. Buccoliero, R.; Ginzburg, L.; Futerman, A.H. Elevation of lung surfactant phosphatidylcholine in mouse models of Sandhoff and of Niemann-Pick A disease. J. Inherit. Metab. Dis. 2004, 27, 641-648. [CrossRef]

15. Buccoliero, R.; Palmeri, S.; Ciarleglio, G.; Collodoro, A.; De Santi, M.M.; Federico, A. Increased lung surfactant phosphatidylcholine in patients affected by lysosomal storage diseases. J. Inherit. Metab. Dis. 2007, 30, 983. [CrossRef]

16. Griese, M.; Brasch, F.; Aldana, V.; Cabrera, M.; Goelnitz, U.; Ikonen, E.; Karam, B.; Liebisch, G.; Linder, M.; Lohse, P. Respiratory disease in Niemann-Pick type C2 is caused by pulmonary alveolar proteinosis. Clin. Genet. 2010, 77, 119-130. [CrossRef] 
17. Roszell, B.R.; Tao, J.-Q.; Yu, K.J.; Huang, S.; Bates, S.R. Characterization of the Niemann-Pick C pathway in alveolar type II cells and lamellar bodies of the lung. Am. J. Physiol. Lung Cell. Mol. Physiol. 2012, 302, L919-L932. [CrossRef]

18. Crawley, A.C.; Gliddon, B.L.; Auclair, D.; Brodie, S.L.; Hirte, C.; King, B.M.; Fuller, M.; Hemsley, K.M.; Hopwood, J.J. Characterization of a C57BL/ 6 congenic mouse strain of mucopolysaccharidosis type IIIA. Brain Res. 2006, 1104, 1-17. [CrossRef]

19. Bhaumik, M.; Muller, V.J.; Rozaklis, T.; Johnson, L.; Dobrenis, K.; Bhattacharyya, R.; Wurzelmann, S.; Finamore, P.; Hopwood, J.J.; Walkley, S.U.; et al. A mouse model for mucopolysaccharidosis type III A (Sanfilippo syndrome). Glycobiology 1999, 9, 1389-1396. [CrossRef]

20. He, Q.Q.; Trim, P.J.; Lau, A.A.; King, B.M.; Hopwood, J.J.; Hemsley, K.M.; Snel, M.F.; Ferro, V. Synthetic disaccharide standards enable quantitative analysis of stored heparan sulfate in MPS IIIA murine brain regions. ACS Chem. Neurosci. 2019, 10, 3847-3858. [CrossRef]

21. Folch, J.; Lees, M.; Sloane-Stanley, G. A simple method for the isolation and purification of total lipids from animal tissues. J. Biol. Chem. 1957, 226, 497-509. [CrossRef]

22. Van Hoecke, L.; Job, E.R.; Saelens, X.; Roose, K. Bronchoalveolar lavage of murine lungs to analyze inflammatory cell infiltration. J. Vis. Exp. 2017. [CrossRef]

23. Bligh, E.G.; Dyer, W.J. A rapid method of total lipid extraction and purification. Can. J. Biochem. Physiol. 1959, 37, 911-917. [CrossRef]

24. Postle, A.D.; Henderson, N.G.; Koster, G.; Clark, H.W.; Hunt, A.N. Analysis of lung surfactant phosphatidylcholine metabolism in transgenic mice using stable isotopes. Chem. Phys. Lipids 2011, 164, 549-555. [CrossRef]

25. Goss, V.; Hunt, A.N.; Postle, A.D. Regulation of lung surfactant phospholipid synthesis and metabolism. Biochim. Biophys. Acta (BBA) Mol. Cell Biol. Lipids 2013, 1831, 448-458. [CrossRef]

26. Schürch, S.; Green, F.H.; Bachofen, H. Formation and structure of surface films: Captive bubble surfactometry. Biochim. Biophys. Acta 1998, 1408, 180-202. [CrossRef]

27. Nanjee, M.N.; Gebre, A.K.; Miller, N.E. Enzymatic fluorometric procedure for phospholipid quantification with an automated microtiter plate fluorometer. Clin. Chem. 1991, 37, 868-874. [CrossRef]

28. Naito, H.K.; David, J.A. Laboratory considerations: Determination of cholesterol, triglyceride, phospholipid, and other lipids in blood and tissues. Lab. Res. Methods Biol. Med. 1984, 10, 1-76.

29. Schoel, W.M.; Schürch, S.; Goerke, J. The captive bubble method for the evaluation of pulmonary surfactant: Surface tension, area, and volume calculations. Biochim. Biophys. Acta (BBA) Gen. Subj. 1994, 1200, 281-290. [CrossRef]

30. Soo, P.S.; Hiscock, J.; Botting, K.J.; Roberts, C.T.; Davey, A.K.; Morrison, J.L. Maternal undernutrition reduces P-glycoprotein in guinea pig placenta and developing brain in late gestation. Reprod. Toxicol. 2012, 33, 374-381. [CrossRef]

31. McGillick, E.V.; Orgeig, S.; McMillen, I.C.; Morrison, J.L. The fetal sheep lung does not respond to cortisol infusion during the late canalicular phase of development. Physiol. Rep. 2013, 1, 1-15. [CrossRef]

32. Bustin, S.A.; Benes, V.; Garson, J.A.; Hellemans, J.; Huggett, J.; Kubista, M.; Mueller, R.; Nolan, T.; Pfaffl, M.W.; Shipley, G.L.; et al. The MIQE Guidelines: Minimum information for publication of quantitative real-time PCR experiments. Clin. Chem. 2009, 55, 611-622. [CrossRef]

33. Darby, J.R.T.; McMillen, I.C.; Morrison, J.L. Maternal undernutrition in late gestation increases IGF2 signalling molecules and collagen deposition in the right ventricle of the fetal sheep heart. J. Physiol. 2018, 596, 2345-2358. [CrossRef]

34. Pillai-Kastoori, L.; Schutz-Geschwender, A.R.; Harford, J.A. A systematic approach to quantitative Western blot analysis. Anal. Biochem. 2020, 593, 113608. [CrossRef]

35. Vieira, F.; Kung, J.W.; Bhatti, F. Structure, genetics and function of the pulmonary associated surfactant proteins A and D: The extra-pulmonary role of these C type lectins. Ann. Anat. Anat. Anz. 2017, 211, 184-201. [CrossRef]

36. Davis, D.A.S.; Parish, C.R. Heparan sulfate: A ubiquitous glycosaminoglycan with multiple roles in immunity. Front. Immunol. 2013, 4, 470 .

37. Ochs, M.; Hegermann, J.; Lopez-Rodriguez, E.; Timm, S.; Nouailles, G.; Matuszak, J.; Simmons, S.; Witzenrath, M.; Kuebler, W.M. On Top of the Alveolar Epithelium: Surfactant and the Glycocalyx. Int. J. Mol. Sci. 2020, 21, 3075. [CrossRef]

38. Stringer, S.E.; Gallagher, J.T. Heparan sulphate. Int. J. Biochem. Cell Biol. 1997, 29, 709-714. [CrossRef]

39. Gallagher, J.T.; Lyon, M.; Steward, W.P. Structure and function of heparan sulphate proteoglycans. Biochem. J. 1986, 236, 313-325. [CrossRef]

40. Lindahl, U.; Kjellén, L. Pathophysiology of heparan sulphate: Many diseases, few drugs. J. Intern. Med. 2013, 273, 555-571. [CrossRef]

41. Smits, N.C.; Shworak, N.W.; Dekhuijzen, P.N.; van Kuppevelt, T.H. Heparan sulfates in the lung: Structure, diversity, and role in pulmonary emphysema. Anat. Rec. 2010, 293, 955-967. [CrossRef]

42. Haeger, S.M.; Yang, Y.; Schmidt, E.P. Heparan sulfate in the developing, healthy, and injured lung. Am. J. Respir. Cell Mol. Biol. 2016, 55, 5-11. [CrossRef]

43. Li, J.P.; Kusche-Gullberg, M. Heparan sulfate: Biosynthesis, structure, and function. In International Review of Cell and Molecular Biology; Jeon, K.W., Ed.; Academic Press: Amsterdam, The Netherlands, 2016; Volume 325, pp. 215-273.

44. Yang, Y.; Schmidt, E.P. The endothelial glycocalyx. Tissue Barriers 2013, 1, e23494. [CrossRef] 
45. Haeger, S.M.; Liu, X.; Han, X.; McNeil, J.B.; Oshima, K.; McMurtry, S.A.; Yang, Y.; Ouyang, Y.; Zhang, F.; Nozik-Grayck, E.; et al. Epithelial heparan sulfate contributes to alveolar barrier function and is shed during lung injury. Am. J. Respir. Cell Mol. Biol. 2018, 59, 363-374. [CrossRef]

46. LaRivière, W.B.; Schmidt, E.P. Chapter Two-The pulmonary endothelial glycocalyx in ARDS: A critical role for heparan sulfate. In Current Topics in Membranes; Belvitch, P., Dudek, S., Eds.; Academic Press: Amsterdam, The Netherlands, 2018; Volume 82, pp. 33-52.

47. Maccari, F.; Sorrentino, N.C.; Mantovani, V.; Galeotti, F.; Fraldi, A.; Volpi, N. Glycosaminoglycan levels and structure in a mucopolysaccharidosis IIIA mice and the effect of a highly secreted sulfamidase engineered to cross the blood-brain barrier. Metab. Brain Dis. 2017, 32, 203-210. [CrossRef]

48. Cañadas, O.; Keough, K.M.W.; Casals, C. Bacterial lipopolysaccharide promotes destabilization of lung surfactant-like films. Biophys. J. 2011, 100, 108-116. [CrossRef]

49. Parra, E.; Pérez-Gil, J. Composition, structure and mechanical properties define performance of pulmonary surfactant membranes and films. Chem. Phys. Lipids 2015, 185, 153-175. [CrossRef]

50. Krafft, M.P. Overcoming inactivation of the lung surfactant by serum proteins: A potential role for fluorocarbons? Soft Matter 2015, 11, 5982-5994. [CrossRef]

51. Devendra, G.; Spragg, R.G. Lung surfactant in subacute pulmonary disease. Respir. Res. 2002, 3, 11. [CrossRef]

52. Amigoni, A.; Pettenazzo, A.; Stritoni, V.; Circelli, M. Surfactants in acute respiratory distress syndrome in infants and children: Past, present and future. Clin. Drug Investig. 2017, 37, 729-736. [CrossRef]

53. Gill, S.E.; Yamashita, C.M.; Veldhuizen, R.A. Lung remodeling associated with recovery from acute lung injury. Cell Tissue Res. 2017, 367, 495-509. [CrossRef]

54. Archer, L.D.; Langford-Smith, K.J.; Bigger, B.W.; Fildes, J.E. Mucopolysaccharide diseases: A complex interplay between neuroinflammation, microglial activation and adaptive immunity. J. Inherit. Metab. Dis. 2014, 37, 1-12. [CrossRef]

55. Bigger, B.; Boutin, H.; Wilkinson, F.; Holley, R.; Brough, D.; Pinteaux, E.; Parker, H. Mucopolysaccharidosis type IIIA storage substrate drives an innate immune neuro-inflammatory response. Mol. Genet. Metab. 2016, 120, S27-S28. [CrossRef]

56. Lopez-Rodriguez, E.; Pérez-Gil, J. Structure-function relationships in pulmonary surfactant membranes: From biophysics to therapy. Biochim. Biophys. Acta (BBA) Biomembr. 2014, 1838, 1568-1585. [CrossRef]

57. Reid, K.B.M. Functional roles of the lung surfactant proteins SP-A and SP-D in innate immunity. Immunobiology 1998, 199, $200-207$. [CrossRef]

58. Al-Saiedy, M.; Tarokh, A.; Nelson, S.; Hossini, K.; Green, F.; Ling, C.-C.; Prenner, E.J.; Amrein, M. The role of multilayers in preventing the premature buckling of the pulmonary surfactant. Biochim. Biophys. Acta (BBA) Biomembr. 2017, 1859, 1372-1380. [CrossRef]

59. Svennerholm, L. The gangliosides. J. Lipid Res. 1964, 5, 145-155. [CrossRef]

60. McGlynn, R.; Dobrenis, K.; Walkley, S.U. Differential subcellular localization of cholesterol, gangliosides, and glycosaminoglycans in murine models of mucopolysaccharide storage disorders. J. Comp. Neurol. 2004, 480, 415-426. [CrossRef]

61. Dautel, S.E.; Kyle, J.E.; Clair, G.; Sontag, R.L.; Weitz, K.K.; Shukla, A.K.; Nguyen, S.N.; Kim, Y.-M.; Zink, E.M.; Luders, T.; et al. Lipidomics reveals dramatic lipid compositional changes in the maturing postnatal lung. Sci. Rep. 2017, 7, 40555. [CrossRef]

62. Walkley, S.U. Secondary accumulation of gangliosides in lysosomal storage disorders. Semin. Cell Dev. Biol. 2004, 15, 433-444. [CrossRef]

63. Tsukuda, Y.; Iwasaki, N.; Seito, N.; Kanayama, M.; Fujitani, N.; Shinohara, Y.; Kasahara, Y.; Onodera, T.; Suzuki, K.; Asano, T.; et al. Ganglioside GM3 Has an Essential Role in the Pathogenesis and Progression of Rheumatoid Arthritis. PLoS ONE 2012, 7, e40136. [CrossRef] [PubMed]

64. Jou, I.; Lee, J.H.; Park, S.Y.; Yoon, H.J.; Joe, E.-H.; Park, E.J. Gangliosides trigger inflammatory responses via TLR4 in brain glia. Am. J. Pathol. 2006, 168, 1619-1630. [CrossRef] [PubMed]

65. Somogyi, A.; Petcherski, A.; Beckert, B.; Huebecker, M.; Priestman, D.A.; Banning, A.; Cotman, S.L.; Platt, F.M.; Ruonala, M.O.; Tikkanen, R. Altered expression of ganglioside metabolizing enzymes results in GM3 ganglioside accumulation in cerebellar cells of a mouse model of juvenile neuronal ceroid lipofuscinosis. Int. J. Mol. Sci. 2018, 19, 625. [CrossRef] [PubMed]

66. Langeveld, M.; Ghauharali, K.J.; Sauerwein, H.P.; Ackermans, M.T.; Groener, J.E.; Hollak, C.E.; Aerts, J.M.; Serlie, M.J. Type I Gaucher disease, a glycosphingolipid storage disorder, is associated with insulin resistance. J. Clin. Endocrinol. Metab. 2008, 93, 845-851. [CrossRef]

67. Ghauharali-van der Vlugt, K.; Langeveld, M.; Poppema, A.; Kuiper, S.; Hollak, C.E.; Aerts, J.M.; Groener, J.E. Prominent increase in plasma ganglioside GM3 is associated with clinical manifestations of type I Gaucher disease. Clin. Chim. Acta 2008, 389, 109-113. [CrossRef]

68. Hullin-Matsuda, F.; Luquain-Costaz, C.; Bouvier, J.; Delton-Vandenbroucke, I. Bis (monoacylglycero) phosphate, a peculiar phospholipid to control the fate of cholesterol: Implications in pathology. Prostaglandinsleukotrienes Essent. Fat. Acids 2009, 81, 313-324. [CrossRef]

69. McCauliff, L.A.; Langan, A.; Li, R.; Ilnytska, O.; Bose, D.; Waghalter, M.; Lai, K.; Kahn, P.C.; Storch, J. Intracellular cholesterol trafficking is dependent upon NPC2 interaction with lysobisphosphatidic acid. eLife 2019, 8, e50832. [CrossRef]

70. Frederick, T.E.; Chebukati, J.N.; Mair, C.E.; Goff, P.C.; Fanucci, G.E. Bis (monoacylglycero) phosphate forms stable small lamellar vesicle structures: Insights into vesicular body formation in endosomes. Biophys. J. 2009, 96, 1847-1855. [CrossRef] 
71. Wardhan, R.; Mudgal, P. Introduction to Biomembranes. In Textbook of Membrane Biology; Springer: Singapore, 2017 ; pp. 1-28. [CrossRef]

72. Gallala, H.D.; Sandhoff, K. Biological function of the cellular lipid BMP-BMP as a key activator for cholesterol sorting and membrane digestion. Neurochem. Res. 2011, 36, 1594-1600. [CrossRef]

73. Jabs, S.; Quitsch, A.; Käkelä, R.; Koch, B.; Tyynelä, J.; Brade, H.; Glatzel, M.; Walkley, S.; Saftig, P.; Vanier, M.T.; et al. Accumulation of bis(monoacylglycero)phosphate and gangliosides in mouse models of neuronal ceroid lipofuscinosis. J. Neurochem. 2008, 106, 1415-1425. [CrossRef]

74. Yang, S.-T.; Kreutzberger, A.J.B.; Lee, J.; Kiessling, V.; Tamm, L.K. The role of cholesterol in membrane fusion. Chem. Phys. Lipids 2016, 199, 136-143. [CrossRef]

75. Roldan, N.; Pérez-Gil, J.; Morrow, M.R.; García-Álvarez, B. Divide \& Conquer: SurfactantpProtein SP-C and cholesterol modulate phase segregation in lung surfactant. Biophys. J. 2017, 113, 847-859. [CrossRef]

76. Orgeig, S.; Daniels, C.B. The comparative biology of pulmonary surfactant: Past, present and future. Comp. Biochem. Physiol. Part A Mol. Integr. Physiol. 2001, 129, 75-89. [CrossRef]

77. Orgeig, S.; Daniels, C.B. The roles of cholesterol in pulmonary surfactant: Insights from comparative and evolutionary studies. Comp. Biochem. Physiol. Part Amolecular Integr. Physiol. 2010, 129, 75-89. [CrossRef]

78. Simons, K.; Ehehalt, R. Cholesterol, lipid rafts, and disease. J. Clin. Investig. 2002, 110, 597-603. [CrossRef]

79. Veldhuizen, R.; Nag, K.; Orgeig, S.; Possmayer, F. The role of lipids in pulmonary surfactant. Biochim. Biophys. Acta 1998, 1408, 90-108. [CrossRef]

80. Wüstneck, R.; Perez-Gil, J.; Wüstneck, N.; Cruz, A.; Fainerman, V.B.; Pison, U. Interfacial properties of pulmonary surfactant layers. Adv. Colloid Interface Sci. 2005, 117, 33-58. [CrossRef]

81. Vockeroth, D.; Gunasekara, L.; Amrein, M.; Possmayer, F.; Lewis, J.F.; Veldhuizen, R.A.W. Role of cholesterol in the biophysical dysfunction of surfactant in ventilator-induced lung injury. Am. J. Physiol. Lung Cell. Mol. Physiol. 2010, 298, L117-L125. [CrossRef]

82. Serrano, A.G.; Pérez-Gil, J. Protein-lipid interactions and surface activity in the pulmonary surfactant system. Chem. Phys. Lipids 2006, 141, 105-118. [CrossRef]

83. Perez-Gil, J.; Weaver, T. Pulmonary surfactant pathophysiology: Current models and open questions. Physiology 2010, $25,132-141$. [CrossRef]

84. Haller, T.; Ortmayr, J.; Friedrich, F.; Völkl, H.; Dietl, P. Dynamics of surfactant release in alveolar type II cells. Proc. Natl. Acad. Sci. USA 1998, 95, 1579-1584. [CrossRef]

85. Ikegami, M.; Hull, W.M.; Yoshida, M.; Wert, S.E.; Whitsett, J.A. SP-D and GM-CSF regulate surfactant homeostasis via distinct mechanisms. Am. J. Physiol. Lung Cell. Mol. Physiol. 2001, 281, L697-L703. [CrossRef]

86. Schürch, S.; Qanbar, R.; Bachofen, H.; Possmayer, F. The surface-associated surfactant reservoir in the alveolar lining. Neonatology 1995, 67 (Suppl. 1), 61-76. [CrossRef]

87. Baumgart, F.; Ospina, O.L.; Mingarro, I.; Rodríguez-Crespo, I.; Pérez-Gil, J. Palmitoylation of pulmonary surfactant protein SP-C is critical for its functional cooperation with SP-B to sustain compression/expansion dynamics in cholesterol-containing surfactant films. Biophys. J. 2010, 99, 3234-3243. [CrossRef]

88. Alcorn, J.L. Chapter 4-Pulmonary surfactant trafficking and homeostasis. In Lung Epithelial Biology in the Pathogenesis of Pulmonary Disease; Sidhaye, V.K., Koval, M., Eds.; Academic Press: Boston, MA, USA, 2017; pp. 59-75. [CrossRef]

89. Korfhagen, T.R.; Sheftelyevich, V.; Burhans, M.S.; Bruno, M.D.; Ross, G.F.; Wert, S.E.; Stahlman, M.T.; Jobe, A.H.; Ikegami, M.; Whitsett, J.A. Surfactant protein-D regulates surfactant phospholipid homeostasis in vivo. J. Biol. Chem. 1998, 273, 28438-28443. [CrossRef]

90. Ikegami, M.; Na, C.-L.; Korfhagen, T.R.; Whitsett, J.A. Surfactant protein D influences surfactant ultrastructure and uptake by alveolar type II cells. Am. J. Physiol.-Lung Cell. Mol. Physiol. 2005, 288, L552-L561. [CrossRef]

91. Ikegami, M.; Grant, S.; Korfhagen, T.; Scheule, R.K.; Whitsett, J.A. Surfactant protein-D regulates the postnatal maturation of pulmonary surfactant lipid pool sizes. J. Appl. Physiol. 2009, 106, 1545-1552. [CrossRef]

92. Martínez-Calle, M.; Olmeda, B.; Dietl, P.; Frick, M.; Pérez-Gil, J. Pulmonary surfactant protein SP-B promotes exocytosis of lamellar bodies in alveolar type II cells. FASEB J. 2018, 32, 4600-4611. [CrossRef]

93. Botas, C.; Poulain, F.; Akiyama, J.; Brown, C.; Allen, L.; Goerke, J.; Clements, J.; Carlson, E.; Gillespie, A.M.; Epstein, C.; et al. Altered surfactant homeostasis and alveolar type II cell morphology in mice lacking surfactant protein D. Proc. Natl. Acad. Sci. USA 1998, 95, 11869-11874. [CrossRef] [PubMed]

94. Weaver, T.E. Synthesis, processing and secretion of surfactant proteins B and C. Biochim. Biophys. Acta (BBA) Mol. Basis Dis. 1998, 1408, 173-179. [CrossRef]

95. Voorhout, W.F.; Veenendaal, T.; Haagsman, H.P.; Weaver, T.E.; Whitsett, J.A.; van Golde, L.M.; Geuze, H.J. Intracellular processing of pulmonary surfactant protein B in an endosomal/lysosomal compartment. Am. J. Physiol. Lung Cell. Mol. Physiol. 1992, 263, L479-L486. [CrossRef] [PubMed]

96. Nogee, L.M.; Garnier, G.; Dietz, H.C.; Singer, L.; Murphy, A.M.; deMello, D.E.; Colten, H.R. A mutation in the surfactant protein B gene responsible for fatal neonatal respiratory disease in multiple kindreds. J. Clin. Investig. 1994, 93, 1860-1863. [CrossRef] [PubMed] 
97. Danhaive, O.; Chapin, C.; Horneman, H.; Cogo, P.E.; Ballard, P.L. Surface film formation in vitro by infant and therapeutic surfactants: Role of surfactant protein B. Pediatric Res. 2015, 77, 340-346. [CrossRef] [PubMed]

98. Bernardino de la Serna, J.; Perez-Gil, J.; Simonsen, A.C.; Bagatolli, L.A. Cholesterol Rules: Direct observation of the coexistend of two fluid phases in native pulmonary surfactant membranes at physiological temperatures. J. Biol. Chem. 2004, 279, 40715-40722. [CrossRef]

99. Ruwisch, J.; Sehlmeyer, K.; Roldan, N.; Garcia-Alvarez, B.; Perez-Gil, J.; Weaver, T.E.; Ochs, M.; Knudsen, L.; Lopez-Rodriguez, E. Air space distension precedes spontaneous fibrotic remodeling and impaired cholesterol metabolism in the absence of surfactant protein C. Am. J. Respir. Cell Mol. Biol. 2020, 62, 466-478. [CrossRef]

100. Glasser, S.W.; Burhans, M.S.; Korfhagen, T.R.; Na, C.-L.; Sly, P.D.; Ross, G.F.; Ikegami, M.; Whitsett, J.A. Altered stability of pulmonary surfactant in SP-C-deficient mice. Proc. Natl. Acad. Sci. USA 2001, 98, 6366-6371. [CrossRef]

101. Kazzi, B.; Lederer, D.; Arteaga-Solis, E.; Saqi, A.; Chung, W.K. Recurrent diffuse lung disease due to surfactant protein C deficiency. Respir. Med. Case Rep. 2018, 25, 91-95. [CrossRef]

102. Glasser, S.W.; Senft, A.P.; Whitsett, J.A.; Maxfield, M.D.; Ross, G.F.; Richardson, T.R.; Prows, D.R.; Xu, Y.; Korfhagen, T.R. Macrophage Dysfunction and Susceptibility to Pulmonary Pseudomonas aeruginosa Infection in Surfactant Protein C-Deficient Mice. J. Immunol. 2008, 181, 621-628. [CrossRef]

103. Nogee, L.M.; Dunbar, A.E.; Wert, S.E.; Askin, F.; Hamvas, A.; Whitsett, J.A. A mutation in the surfactant protein C gene associated with familial interstitial lung disease. N. Engl. J. Med. 2001, 344, 573-579. [CrossRef]

104. Nogee, L. Alterations in SP-B and SP-C expression in neonatal lung disease. Annu. Rev. Physiol. 2004, 66, 601-623. [CrossRef]

105. Delestrain, C.; Blanchon, S.; Abbal, J.; Nattes, E.; Aissat, A.; Delattre, V.; Simon, S.; Tarze, A.; Bremont, F.; Epaud, R.; et al. A novel non-BRICHOS surfactant protein C mutation causing infantile interstitial lung disease is associated with reduced mature SP-C level. Eur. Respir. J. 2018, 52, PA633.

106. Griese, M.; Lorenz, E.; Hengst, M.; Schams, A.; Wesselak, T.; Rauch, D.; Wittmann, T.; Kirchberger, V.; Escribano, A.; Schaible, T.; et al. Surfactant proteins in pediatric interstitial lung disease. Pediatric Res. 2016, 79, 34-41. [CrossRef]

107. Hong, D.; Dai, D.; Liu, J.; Zhang, C.; Jin, T.; Shi, Y.; Jiang, G.; Mei, M.; Wang, L.; Qian, L. Clinical and genetic spectrum of interstitial lung disease in Chinese children associated with surfactant protein C mutations. Ital. J. Pediatrics 2019, 45, 117. [CrossRef]

108. McCormack, F.X.; Whitsett, J.A. The pulmonary collectins, SP-A and SP-D, orchestrate innate immunity in the lung. J. Clin. Investig. 2002, 109, 707-712. [CrossRef]

109. Kishore, U.; Greenhough, T.J.; Waters, P.; Shrive, A.K.; Ghai, R.; Kamran, M.F.; Bernal, A.L.; Reid, K.B.; Madan, T.; Chakraborty, T. Surfactant proteins SP-A and SP-D: Structure, function and receptors. Mol. Immunol. 2006, 43, 1293-1315. [CrossRef]

110. Pastva, A.M.; Wright, J.R.; Williams, K.L. Immunomodulatory roles of surfactant proteins A and D: Implications in lung disease. Proc. Am. Thorac. Soc. 2007, 4, 252-257. [CrossRef]

111. Schürch, S.; Possmayer, F.; Cheng, S.; Cockshutt, A.M. Pulmonary SP-A enhances adsorption and appears to induce surface sorting of lipid extract surfactant. Am. J. Physiol. Lung Cell. Mol. Physiol. 1992, 263, L210-L218. [CrossRef]

112. Schürch, S.; Schurch, D.; Curstedt, T.; Robertson, B. Surface activity of lipid extract surfactant in relation to film area compression and collapse. J. Appl. Physiol. 1994, 77, 974-986. [CrossRef]

113. Clark, H.; Palaniyar, N.; Strong, P.; Edmondson, J.; Hawgood, S.; Reid, K.B.M. Surfactant Protein D Reduces Alveolar Macrophage Apoptosis In Vivo. J. Immunol. 2002, 169, 2892-2899. [CrossRef]

114. Autilio, C.; Pérez-Gil, J. Understanding the principle biophysics concepts of pulmonary surfactant in health and disease. Arch. Dis. Child. Fetal Neonatal Ed. 2019, 104, F443-F451. [CrossRef]

115. Nag, K.; Rodriguez-Capote, K.; Panda, A.K.; Frederick, L.; Hearn, S.A.; Petersen, N.O.; Schürch, S.; Possmayer, F. Disparate effects of two phosphatidylcholine binding proteins, C-reactive protein and surfactant protein A, on pulmonary surfactant structure and function. Am. J. Physiol. Lung Cell. Mol. Physiol. 2004, 287, L1145-L1153. [CrossRef] [PubMed]

116. Holm, B.A.; Wang, Z.; Notter, R.H. Multiple Mechanisms of Lung Surfactant Inhibition. Pediatric Res. 1999, 46, 85-93. [CrossRef] [PubMed]

117. Kolomaznik, M.; Nova, Z.; Calkovska, A. Pulmonary surfactant and bacterial lipopolysaccharide: The interaction and its functional consequences. Physiol. Res. 2017, 66. [CrossRef] [PubMed]

118. Viana, G.M.; Priestman, D.A.; Platt, F.M.; Khan, S.; Tomatsu, S.; Pshezhetsky, A.V. Brain Pathology in Mucopolysaccharidoses (MPS) Patients with Neurological Forms. J. Clin. Med. 2020, 9, 396. [CrossRef] [PubMed]

119. Lewith, H.; Pandit, J.J. Lung ventilation and the physiology of breathing. Surgery 2020, 38, 233-239. [CrossRef] 